\title{
Transcriptional corepressor SIN3A regulates hippocampal synaptic plasticity via Homer1/mGluR5 signaling
}

\author{
Morgan Bridi, ${ }^{1}$ Hannah Schoch, ${ }^{2}$ Cédrick Florian, ${ }^{3}$ Shane G. Poplawski, ${ }^{4}$ Anamika Banerjee, ${ }^{5}$ \\ Joshua D. Hawk, ${ }^{1}$ Giulia S. Porcari, ${ }^{3}$ Camille Lejards, ${ }^{6}$ Chang-Gyu Hahn, ${ }^{5}$ Karl-Peter Giese, ${ }^{7}$ \\ Robbert Havekes, ${ }^{3}$ Nelson Spruston, ${ }^{8}$ and Ted Abel $^{3}$ \\ ${ }^{1}$ Mahoney Institute for Neurosciences, ${ }^{2}$ Cell and Molecular Biology Graduate Group, ${ }^{3}$ Department of Biology, \\ ${ }^{4}$ Pharmacology Graduate Group, and ${ }^{5}$ Department of Psychiatry, University of Pennsylvania, Philadelphia, Pennsylvania, USA \\ ${ }^{6}$ Université Paul Sabatier, Toulouse, France. ${ }^{7}$ King's College, London, United Kingdom. ${ }^{8}$ Howard Hughes Medical Institute \\ (HHMI) Janelia Research Campus, Ashburn, Virginia, USA
}

Long-term memory depends on the control of activity-dependent neuronal gene expression, which is regulated by epigenetic modifications. The epigenetic modification of histones is orchestrated by the opposing activities of 2 classes of regulatory complexes: permissive coactivators and silencing corepressors. Much work has focused on coactivator complexes, but little is known about the corepressor complexes that suppress the expression of plasticity-related genes. Here, we define a critical role for the corepressor SIN3A in memory and synaptic plasticity, showing that postnatal neuronal deletion of Sin3a enhances hippocampal long-term potentiation and longterm contextual fear memory. SIN3A regulates the expression of genes encoding proteins in the postsynaptic density. Loss of SIN3A increases expression of the synaptic scaffold Homer1, alters the metabotropic glutamate receptor $1 \alpha$ (mGluR1 $\alpha$ ) and mGluR5 dependence of long-term potentiation, and increases activation of ERK in the hippocampus after learning. Our studies define a critical role for corepressors in modulating neural plasticity and memory consolidation and reveal that Homer1/ mGluR signaling pathways may be central molecular mechanisms for memory enhancement.

Authorship note: MB and HS contributed equally to this work.

Conflict of interest: The authors have declared that no conflict of interest exists.

Copyright: (c) 2020, American Society for Clinical Investigation.

Submitted: January 17, 2017

Accepted: February 12, 2020

Published: February 18, 2020

Reference information: JCI Insight. 2020;5(5):e92385.

https://doi.org/10.1172/jci.

insight. 92385 .

\section{Introduction}

Long-term memory consolidation and hippocampal long-term potentiation (LTP) depend on activity-dependent neuronal gene expression, which is, in turn, regulated by epigenetic mechanisms such as posttranslational histone modifications $(1,2)$. Histone acetylation is associated with transcriptional activation, and both histone acetylation and expression of acetylation-regulated genes are increased during memory consolidation (1, 3-5). Acetylation levels are determined by the activity of histone acetyltransferase (HAT) and histone deacetylase (HDAC) enzymes, which are recruited to chromatin by association with coactivator and corepressor proteins (6-8). For example, HATs such as CBP and p300 are recruited by the transcription factor and coactivator protein CREB in response to signaling cascades triggered by synaptic activity (9). The CREB-CBP/p300 complex can regulate transcription through HAT activity, as well as association with other plasticity-related transcription factors, and genetic studies have demonstrated critical roles for CREB, CBP, and p300 in memory and synaptic plasticity $(6,10,11)$. Conversely, HDACs and other histone-modifying effector enzymes are recruited by corepressor proteins such as NCoR, SIN3A, MI-2 (NuRD), and CoREST (12). In neurons, corepressors have been linked to dynamic and activity-dependent regulation of gene expression, and neuron-specific components of corepressor complexes have also been described (12), suggesting that these proteins are important in regulating transcription-dependent plasticity. However, few studies have directly addressed the function of the corepressor proteins in memory and plasticity.

SIN3A is a highly conserved corepressor protein expressed throughout the brain, in neuronal and in nonneuronal cells. Through its histone-interacting domain (HID), SIN3A recruits a core complex that includes the histone binding proteins RBAP46/48, stabilizing proteins SAP18/20 and SDS3, and the Class I HDAC enzymes HDAC1 and HDAC2 $(13,14)$. Four paired-amphipathic helix (PAH) domains mediate binding of the SIN3A-HDAC complex to transcription factors, DNA binding factors, and other corepressor 
proteins, facilitating the dynamic recruitment of SIN3A to chromatin $(13,14)$. The binding partners of the SIN3A-HDAC complex include several factors linked to neuronal function and cognition, including MEF2, MECP2, NCoR, REST, and CoREST $(12,14)$. Members of the core SIN3A complex, especially HDAC2, have also been shown to regulate memory and plasticity $(8,15)$. Recently, mutations in Sin3a have been linked to several cases of autism spectrum disorder and mild intellectual disability in humans, and in vivo knockdown of $\operatorname{Sin} 3 a$ in mouse embryos was shown to lead to dysfunctional cortical neuronal development (16). These findings suggest that the SIN3A corepressor complex is in a position to act as a critical regulator of neuronal function and cognition, but this corepressor and its function in the mature nervous system have not been studied.

Pharmacological inhibition of HDAC enzymes facilitates robust enhancements in long-term memory and $\operatorname{LTP}(3,6,10)$. Although a number of acetylation-regulated genes have been identified in these studies, it remains to be defined which downstream mechanisms mediate the enhancement of synaptic plasticity and memory at the level of synaptic function. Similarly, while HDAC2 has been identified as a negative regulator of memory and plasticity in the hippocampus (8), the mechanisms by which it is recruited to its regulatory targets and ultimately leads to changes in synaptic function has received little attention. Interestingly, blocking the HDAC binding site on the corepressor NCOR recapitulates the effect of HDAC inhibitor drugs on object memory, highlighting the critical role for corepressors in bringing epigenetic regulators to gene loci (7). Here, we address the function of corepressors in memory storage and synaptic plasticity by conditionally deleting the corepressor SIN3A in excitatory neurons, demonstrating a role for the SIN3A-HDAC corepressor complex as a negative regulator of memory and plasticity that exerts its downstream effects through the synaptic scaffold protein Homer1 and the Group I metabotropic glutamate receptors (mGluRs).

\section{Results}

Deletion of Sin3a from forebrain excitatory neurons enhances LTP. To explore the role of SIN3A in synaptic plasticity and memory consolidation, we used the Cre-loxP system to conditionally delete the Sin3a gene in forebrain excitatory neurons (Figure 1A). SIN3A protein is reduced by approximately $50 \%$ in the hippocampus of $\operatorname{Sin} 3$ a neuronal hypomorphs $(\operatorname{Sin} 3 \mathrm{aNH})$ relative to control animals (1-way ANOVA, $\mathrm{F}_{[1,10]}=$ 32.74, $P<0.001$ ) (Figure 1, B and C; full Western blot appears in Supplemental Figure 8; supplemental material available online with this article; https://doi.org/10.1172/jci.insight.92385DS1). SIN3A binds HDAC1 and HDAC2, and mediates transcriptional repression through interactions with multiple transcription factors and epigenetic regulatory proteins that have been linked to both positive and negative regulation of gene transcription (Figure 1D).

HDAC inhibition enhances hippocampal LTP, transforming short-lasting LTP into long-lasting, transcription-dependent LTP $(3,7)$. Because SIN3A is a scaffold protein that recruits both HDAC1 and HDAC2 to sites of transcriptional regulation, we hypothesized that reduced neuronal $\operatorname{Sin} 3 a$ would mimic the effects of HDAC inhibition and enhance hippocampal LTP. In hippocampal slices from WT control mice, a single tetanus ( 1 second, $100 \mathrm{~Hz}$ ) induces short-lasting LTP that returns to baseline levels within 1 or 2 hours after stimulation $(6,17)$. In $\operatorname{Sin} 3 \mathrm{aNH}$ slices, the same weak stimulus produces sustained potentiation that is significantly higher than in controls (controls, $n=5$; $\operatorname{Sin} 3 \mathrm{aNH}, n=7$; 1-way repeated measures ANOVA, genotype, $\mathrm{F}_{[1,10]}=7.713, P=0.0195$; Figure 2A). This LTP enhancement in Sin3aNH slices is blocked by the transcription inhibitor actinomycin D (Supplemental Figure 1). We also tested basal synaptic properties, paired-pulse facilitation, and synaptic stability at the Schaffer collateral synapses of area CA1. These electrophysiological properties were unchanged in the $\operatorname{Sin} 3 \mathrm{aNH}$ mice, indicating that synaptic transmission and the stability and health of slices are not affected by reduced neuronal $\operatorname{Sin} 3 a$ (Figure 2, B-E). Given the enhancement in hippocampal LTP by Sin3a deletion, we next investigated the ability of an HDAC inhibitor to further enhance LTP in Sin3aNH mice. As demonstrated previously (6), the combination of a single tetanus and administration of the HDAC inhibitor Trichostatin A (TSA) enhances LTP in WT control slices (controls + veh, $n=4$; controls + TSA, $n=6$; 2-way repeated measures ANOVA; genotype, $\mathrm{F}_{[1,16]}=10.604, P=0.005$; treatment, $\mathrm{F}_{[1,16]}$ $=5.111, P=0.038$; genotype $\times$ treatment interaction, $\mathrm{F}_{[1,16]}=5.151, P=0.037$; Tukey's post hoc, controls + veh vs. controls + TSA, $P=0.026$; Figure 3A). However, in Sin3aNH mice, TSA administration did not enhance LTP compared with vehicle-treated slices ( $\operatorname{Sin} 3 \mathrm{aNH}+\mathrm{veh}, n=4$; $\operatorname{Sin} 3 \mathrm{aNH}+\mathrm{TSA}, n=6$; Tukey's post hoc, $\operatorname{Sin} 3 \mathrm{aNH}+$ veh vs. Sin3aNH + TSA, $P=0.999$; Figure 3B). Further, LTP in Sin3aNH slices was significantly greater than in vehicle-treated control slices but was similar to TSA-treated control slices (2-way 


\section{A}

$\sin 3 a$

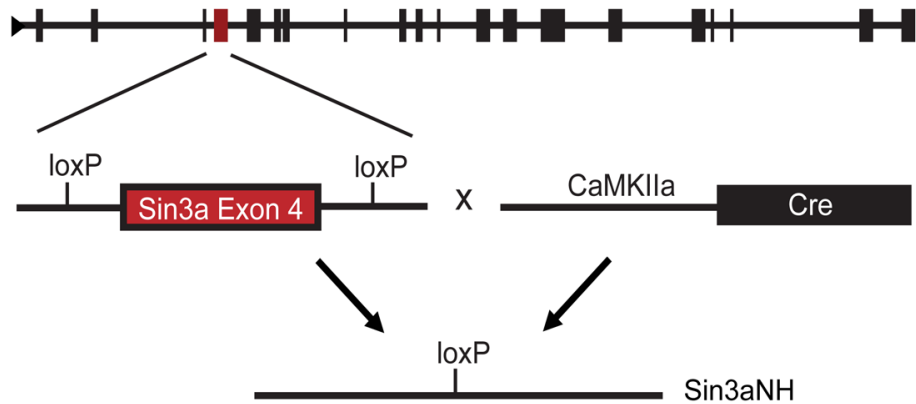

B

B Control Sin3aNH control Sin3aNH
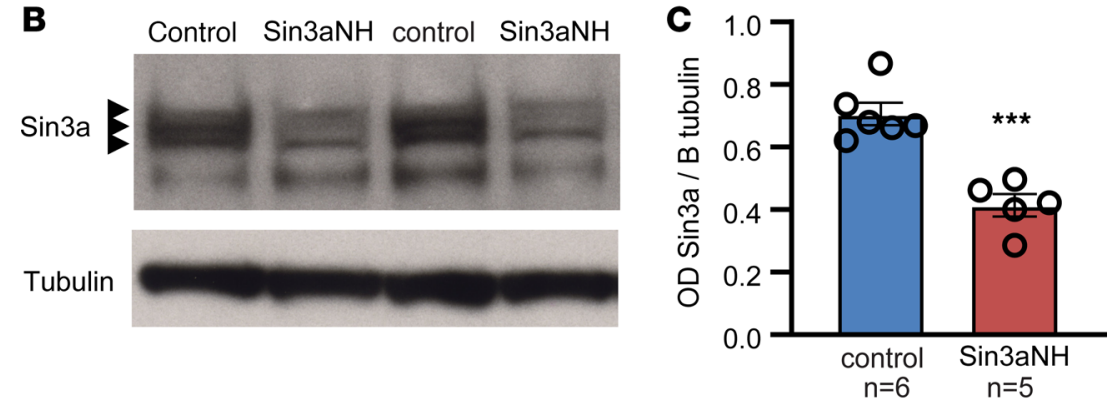

D

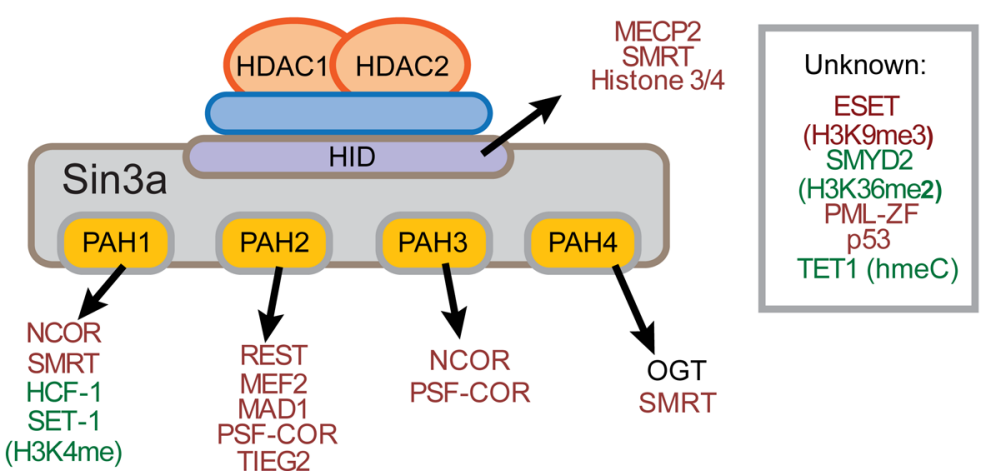

Figure 1. Sin3a neuronal hypomorphs have reduced levels of SIN3A in the hippocampus. (A) Structure of murine Sin3a locus with exon 4 highlighted. Recombination via CaMKIl $\alpha$ promoter-driven Cre at 1 or more Sin $3 a^{\text {LoxP }}$ alleles results in deletion of exon 4 of $\operatorname{Sin} 3 a$. (B) Sin3aNH mice have decreased SIN3A protein levels (arrows) in the hippocampus by immunoblot. (C) Quantification of optical density of SIN3A bands (arrows $\mathbf{C}$ ) normalized to $\beta$ tubulin loading control (controls, $n=6$; $\operatorname{Sin} 3 a N H, n=5$; 1-way ANOVA; $F_{[1.9]}=32.74 ;{ }^{* *} P<0.001$ ). (D) The HID domain and 4 PAH domains of SIN3A mediate interactions with cofactors, epigenetic modifiers, and transcription factors. SIN3A-interacting factors have been linked to both permissive (green) and repressive (red) regulation of gene transcription. Data are presented as mean $\pm \mathrm{SEM}$.

repeated measures ANOVA with Tukey's post hoc test, control + veh vs. Sin3aNH + veh, $P=0.012$; control + veh vs. $\operatorname{Sin} 3 \mathrm{aNH}+\mathrm{TSA}, P=0.006$; control + TSA vs. Sin $3 \mathrm{aNH}+$ veh, $P=0.894$; control + TSA vs. Sin $3 \mathrm{aNH}+\mathrm{TSA}, P=0.862$; Figure $3 \mathrm{C}$ ). The occlusion of the effects of TSA on LTP in Sin 3 aNH mice and the similarity of LTP enhancement by Sin3a deletion to LTP enhancement by HDAC inhibitor treatment suggest that the changes we observe here in synaptic plasticity are a phenocopy of HDAC inhibition and that the enhanced LTP phenotypes share a common underlying mechanism.

Reduced $\operatorname{Sin} 3 a$ in forebrain excitatory neurons enhances hippocampal long-term memory. To determine whether reduction of neuronal $\operatorname{Sin} 3 a$ impacts memory consolidation, we tested associative memory in $\mathrm{Sin} 3 \mathrm{aNH}$ animals using the contextual fear-conditioning paradigm. We tested long-term memory in Sin $3 \mathrm{aNH}$ and WT control animals in the foreground contextual fear paradigm, a cognitive task that engages the hippocampus $(18,19)$. Sin $3 \mathrm{aNH}$ animals show enhanced long-term memory compared with controls when tested 24 hours after conditioning (independent samples Kruskal-Wallis; effect of genotype, preshock, $P<0.13$; 24-hour 2-tailed unpaired $t$ test, $P<0.008$; Figure 4A). Consolidation of 

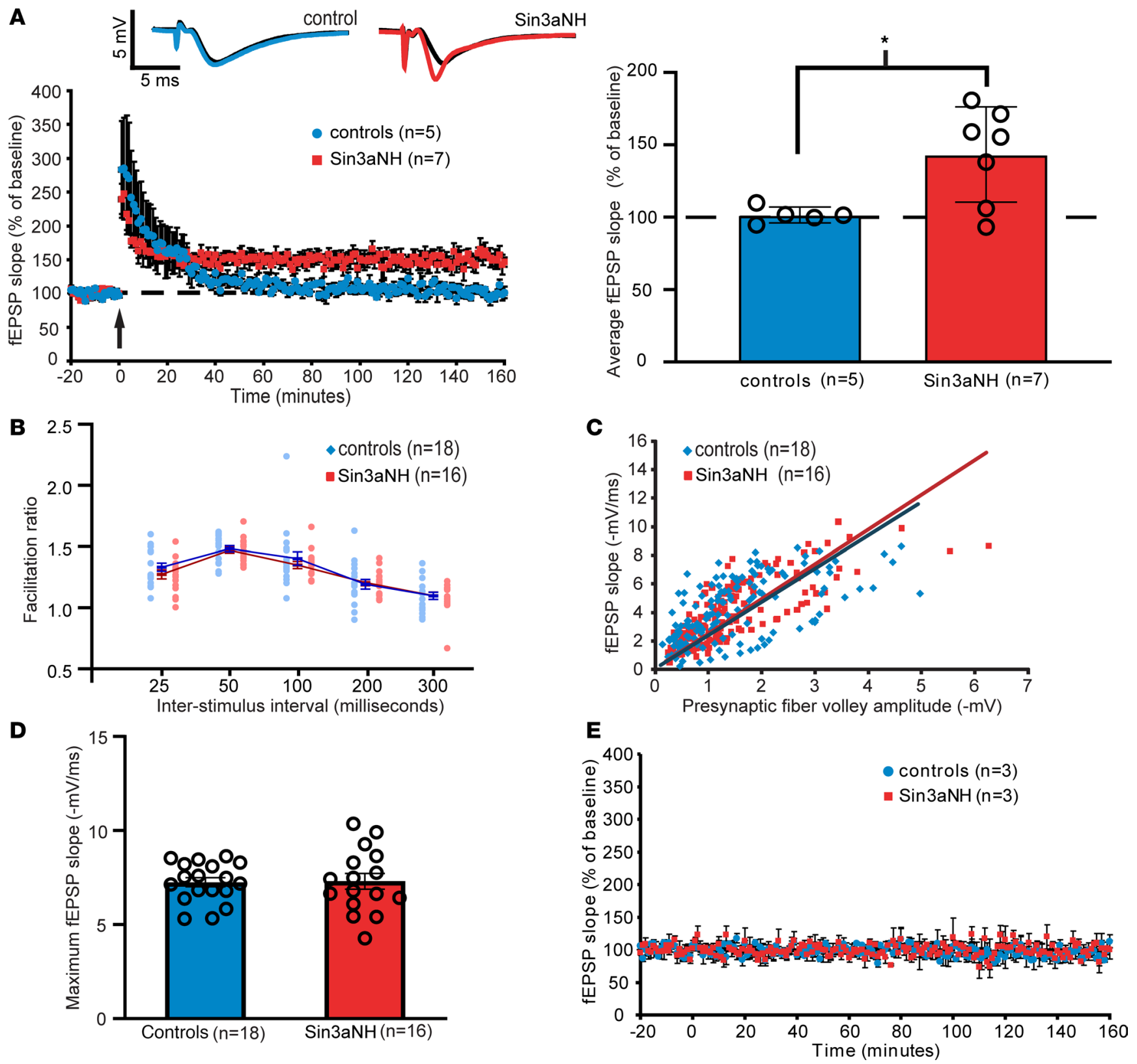

Figure 2. Neuronal deletion of SIN3A enhances hippocampal LTP but does not change basal synaptic properties at the Schaffer collateral synapses. (A) LTP was induced by a single $100 \mathrm{~Hz}$, 1-second-duration stimuli (indicated by arrow). LTP maintenance was significantly enhanced in Sin3aNH mice (controls, $n=5$; avg. of fEPSP slope over final $20 \mathrm{~min}=101.55 \% \pm 2.03 \%$; Sin3aNH, $n=7$; avg. of fEPSP slope over final $20 \mathrm{~min}=151.72 \% \pm 10.88 \%$; repeated measures ANOVA, genotype, $F_{[1,10]}=7.713,{ }^{*} P=0.0195$ ). (B) Paired-pulse facilitation was unchanged in hippocampal slices from Sin3aNH mice (controls, $n=18$; Sin3aNH, $n=16$; 1-way repeated measures ANOVA, genotype, $\mathrm{F}_{[1,32]}=0.364, P=0.55$; genotype $\times$ interval interaction, $\mathrm{F}_{[4,128]}=0.769, P=$ 0.547). (C) Input-output relationships were not different in Sin3aNH mice compared with WT controls (controls, $n=18$; Sin3aNH, $n=16$; 2-tailed independent samples $t$ test on average of regression slopes, $\left.\mathrm{t}_{[1,32]}=1.324, P=0.189\right)$. (D) The maximum amplitude of fEPSP slopes recorded in slices from Sin3aNH mutant mice and WT control animals were not significantly different (controls, $n=18$; Sin3aNH, $n=16$; 2-tailed independent samples $t$ test, $\left.\mathrm{t}_{[1,32]}=0.11, P=0.913\right)$. (E) Baseline synaptic response in the absence of stimulation is not altered in Sin3aNH mutants when compared with WT controls (controls, $n=3$; avg. fEPSP slope $=94.32 \% \pm 7.78 \%$; Sin3aNH, $n=3$; avg. fEPSP slope $=95.12 \% \pm 6.58 \%$; 2-way repeated measures ANOVA, genotype, $\left.\mathrm{F}_{[1,4]}=0.092, P=0.777\right)$. All data are presented as mean $\pm \mathrm{SEM}$.

long-term (24-hour) hippocampal fear memory requires transcriptional activation and translation of new proteins, but short-term (1-hour) memory does not $(20,21)$. When we tested a second naive cohort of animals for short-term contextual fear memory 1 hour after training, we found no differences in the freezing responses of Sin $3 \mathrm{aNH}$ and control animals to the training context (2-way ANOVA; genotype, $\mathrm{F}_{[1,44]}=0.05, P<0.83$; phase, $\mathrm{F}_{[1,44]}=94.1, P<0.001 ;$ Figure 4B). Previous studies of fear learning cir- 
A
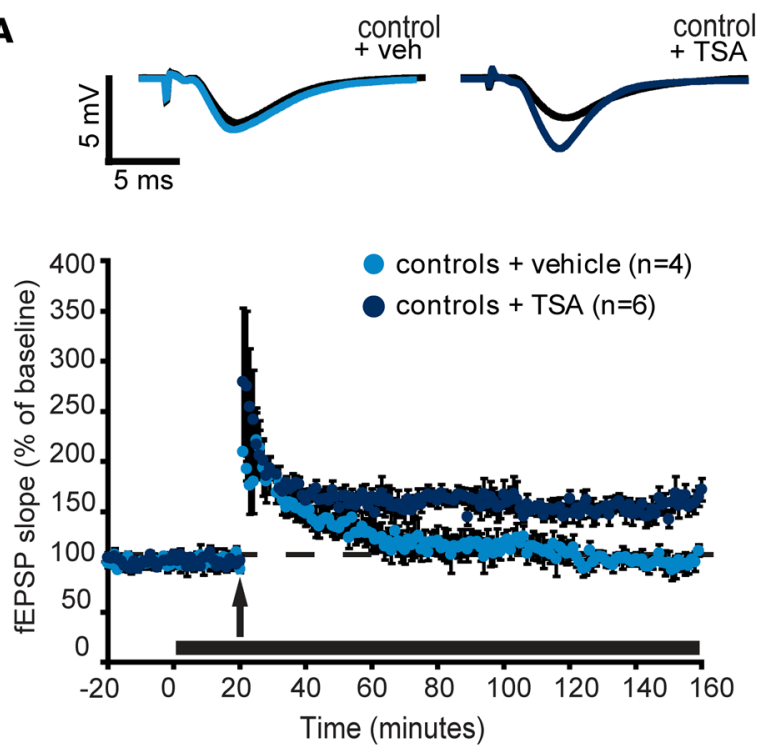

B
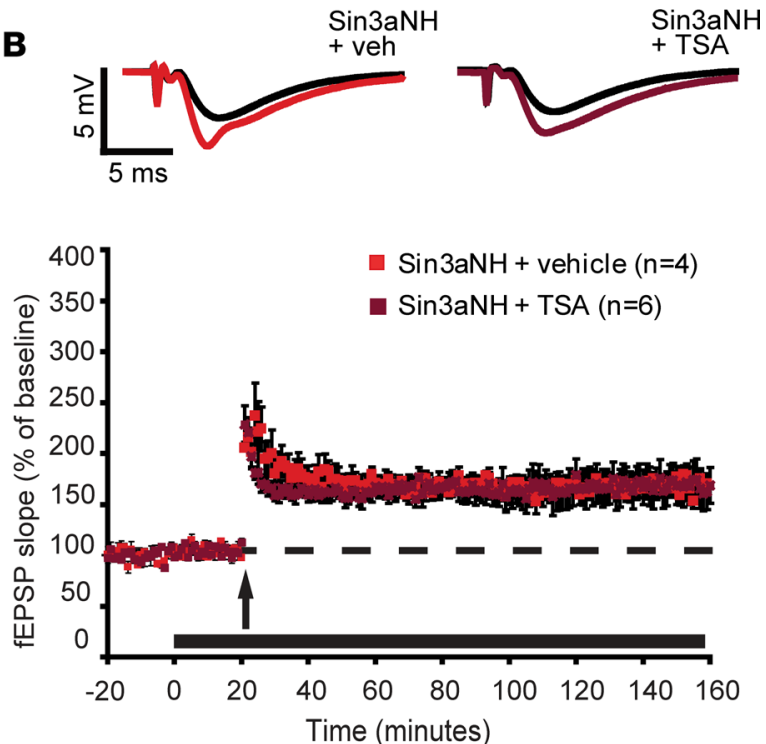

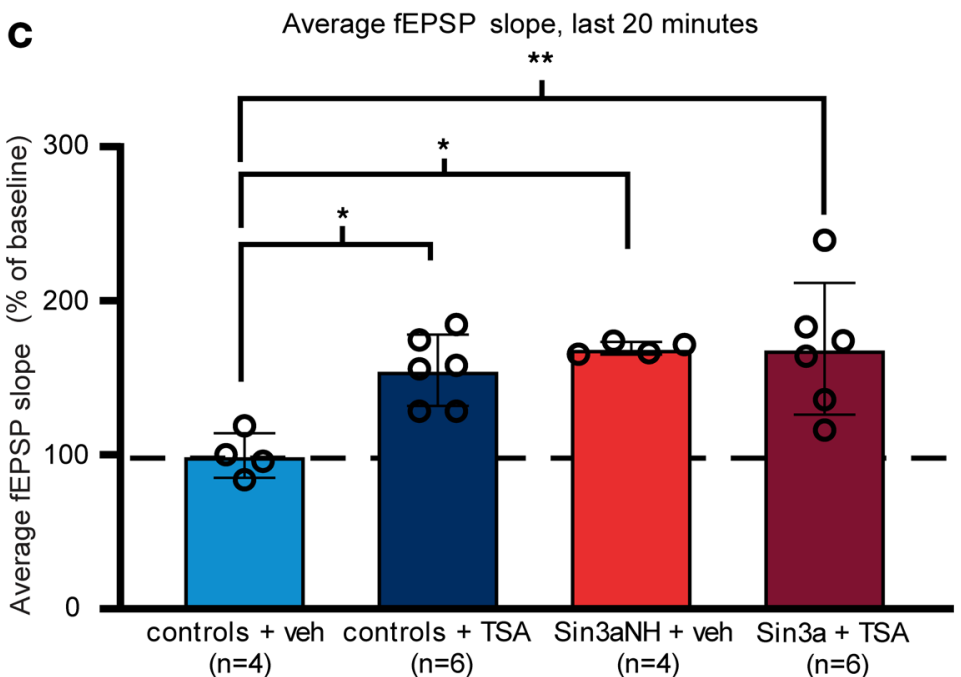

Figure 3. LTP enhancement by HDAC inhibitor administration is occluded in Sin3a neuronal hypomorphs. (A) In control slices, perfusion with 1.65 $\mu \mathrm{M}$ TSA enhanced 1-train LTP compared with vehicle (controls + veh, $n=4$; avg. fEPSP slope $=99.71 \% \pm 7.24 \%$; controls + TSA, $n=6$; avg. fEPSP slope $=$ $155.01 \% \pm 9.47 \%$; 2-way repeated measures ANOVA, genotype, $\mathrm{F}_{[1,16]}=10.604, P=0.005$; treatment, $\mathrm{F}_{[1,16]}=5.111, P=0.038$; genotype $\times$ treatment interaction, $\mathrm{F}_{[1,16]}=5.151, P=0.037$ ). (B) In Sin3aNH slices, TSA administration did not enhance LTP compared with vehicle (Sin3aNH + veh, $n=4$; avg. fEPSP slope $=168.82 \% \pm 2.05 \%$; Sin3aNH + TSA, $n=6$; avg. fEPSP slope $=169.34 \% \pm 17.4 \%$; Tukey's post hoc, Sin3aNH + veh vs. Sin3aNH + TSA, $P=0.999)$. (C) Average fEPSP slopes over final 20 minutes from all groups. No significant difference was observed between control + TSA, Sin3aNH + veh, and Sin3a + TSA groups; these groups all displayed higher potentiation than control + veh slices (2-way repeated measures ANOVA; Tukey's post hoc, controls + veh vs. controls + TSA, ${ }^{*} P=0.026$; Tukey's post hoc, control + veh vs. Sin3aNH + veh, ${ }^{*} P=0.012$; control + veh vs. Sin3aNH + TSA, ${ }^{*} P=0.006$; control + TSA vs. Sin3aNH + veh, $P=0.894$; control + TSA vs. Sin3aNH + TSA, $P=0.862$ ). All data are presented as mean \pm SEM.

cuitry suggest that associative fear conditioning to a tone cue is dependent on the amygdala but not on the hippocampus $(22,23)$. When we conditioned a third cohort of Sin $3 \mathrm{aNH}$ animals in the tone-cued fear task, no differences were seen in either baseline freezing pre-CS, or during CS tone presentation (2-way ANOVA; genotype, $\mathrm{F}_{[1,22]}=0.1, P<0.77$; phase, $\mathrm{F}_{[1,22]}=21.0, P<0.001$ ); Figure $4 \mathrm{C}$ ). This finding, together with the enhanced LTP we found in Sin3aNH hippocampal slices (Figure 2), suggests that the contextual memory enhancements we observed may be specifically due to changes in hippocampal function. We next examined mice for anxiety-related behaviors in the elevated zero maze. Sin $3 \mathrm{aNH}$ mice show increased time spent in the open sections (2-tailed unpaired $t$ test, $P<0.01$ ) compared with controls, a result suggestive of decreased anxiety in the Sin3aNH animals (Figure 4D). The low levels of anxiety-like behaviors in the Sin3aNH mice, together with the absence of changes in both 1-hour 
A

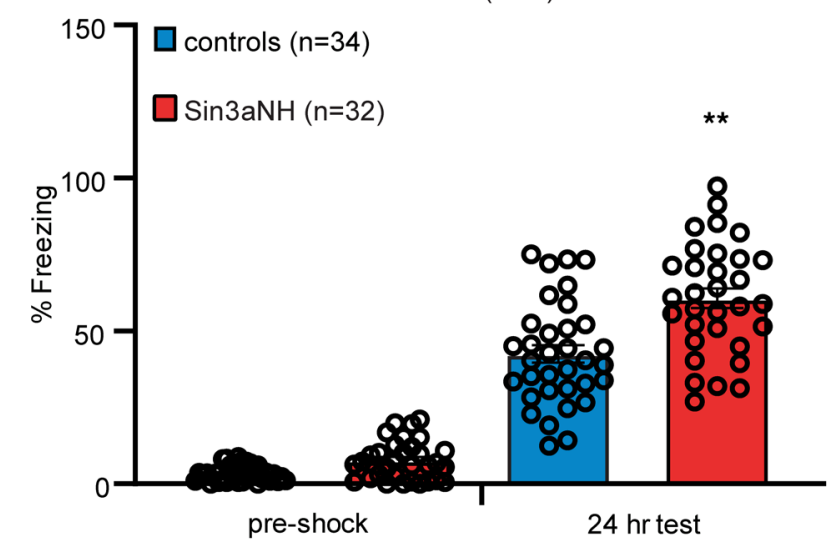

CONTEXT (LTM)

C

CUE (LTM)

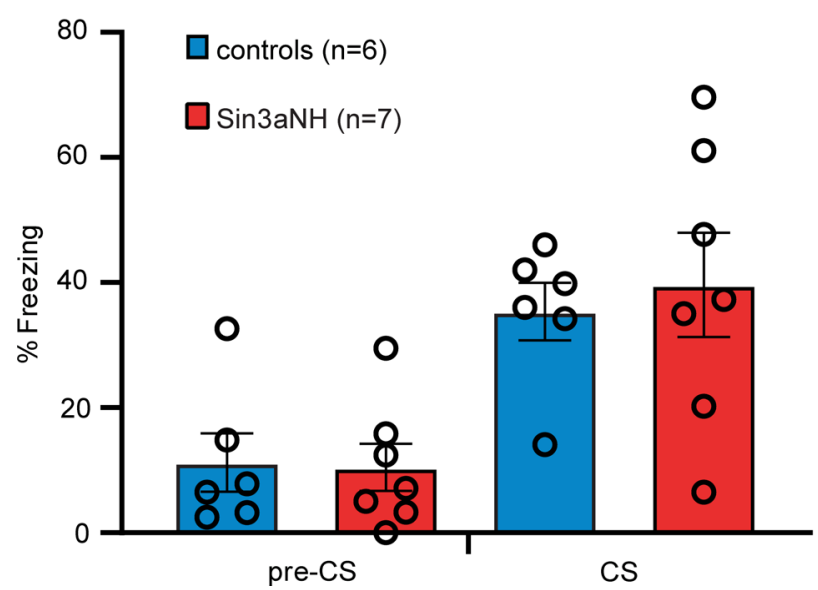

B

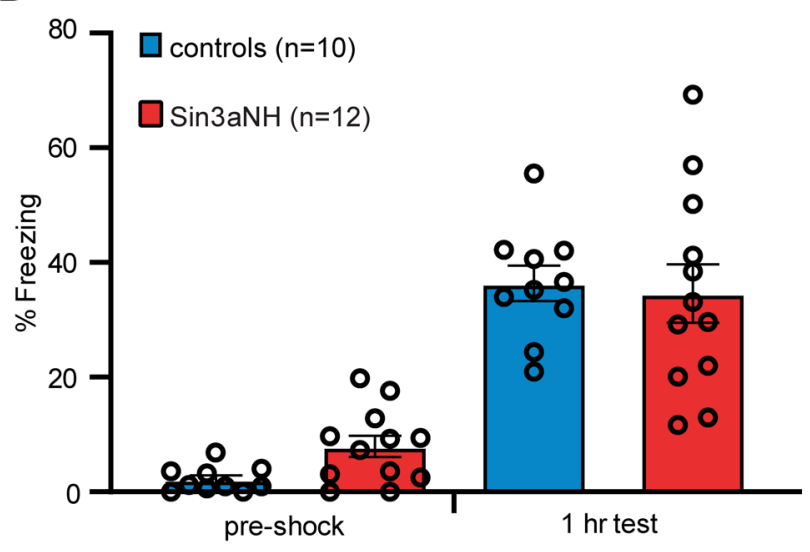

D

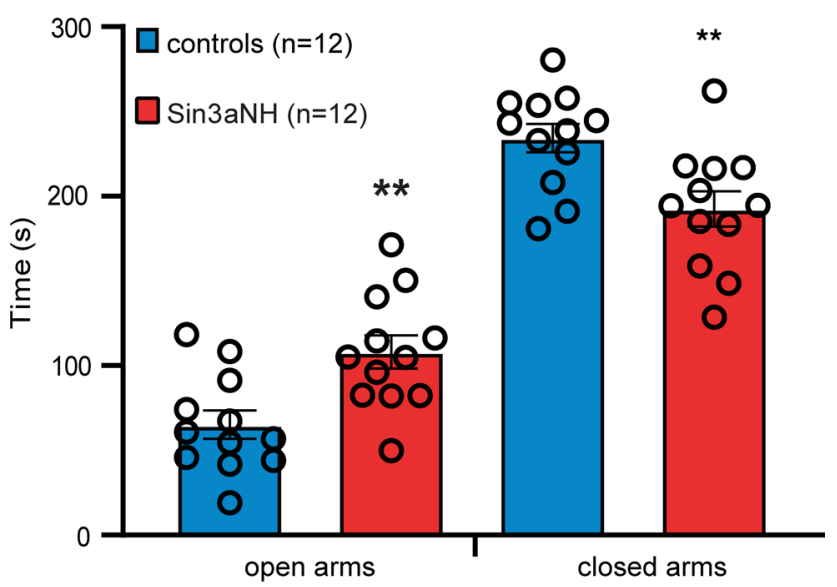

Figure 4. Sin3aNH mice have enhanced long-term memory. (A) Sin3aNH animals have enhanced 24-hour long-term memory for contextual fear conditioning (control, $n=34$; Sin3aNH, $n=32$; independent samples Kruskal-Wallis test; effect of genotype, preshock $P<0.13 ; 24$-hour test ** $P<0.008$ ). (B) No effect of Sin3a reduction on short-term memory (1-hour) for contextual fear conditioning (control, $n=10$; Sin3aNH, $n=12$; 2-way ANOVA; genotype, $F_{[1,44]}=0.05, P<0.83$; phase, $F_{[1,44]}=94.1, P<0.001$ ). (C) Cued-fear long-term memory (24-hour) is not altered in Sin3aNH animals (control, $n=6$; Sin3aNH, $n=7$; 2-way ANOVA; genotype, $\mathrm{F}_{[1,22]}=0.1 ; P<0.77$; phase, $\left.\mathrm{F}_{[1,22]}=21.0, P<0.001\right)$. (D) In the elevated zero maze, Sin3aNH mice spend more time in the open arms ( $n=12$ per group; 2 -tailed independent samples $t$ test, $\left.\mathrm{t}_{[1,22]}=3.342,{ }^{* *} P<0.01\right)$ and less time in the closed arms $\left(t\right.$ test, $\left.{ }^{* *} P<0.01\right)$ compared with control animals. All data are presented as mean \pm SEM.

contextual and cued fear responses, strongly argue against general fear abnormalities in these animals. Rather, these results indicate that reducing the function of the SIN3A corepressor in excitatory neurons enhances hippocampal long-term memory.

Reduction of neuronal SIN3A changes memory-related gene expression and synaptic signaling. The effects of SIN3A depletion on transcription-dependent forms of long-term memory and synaptic plasticity support a role for the SIN3A-HDAC complex in regulating the expression of genes involved in neuronal plasticity. Because manipulation of HDACs (whether pharmacologically or genetically) can induce broad changes in gene expression $(8,24,25)$, we sought to use a candidate approach to study genes more specifically associated with the SIN3A repressor complex by focusing on gene loci linked to memory and synaptic plasticity that have been shown by others to be regulated by both HDAC2 and SIN3A (NHGRI ENCODE, http://genome.ucsc.edu/) (8, 26, 27). To investigate whether expression of these candidate target genes is altered in Sin $3 \mathrm{aNH}$ mice, we collected hippocampal tissue from Sin $3 \mathrm{aNH}$ and control animals 1 hour after contextual fear conditioning and measured mRNA transcript levels by quantitative PCR (qPCR). Neuronal depletion of SIN3A alters mRNA expression of a subset of HDAC2-regulated synaptic genes, increasing levels of transcripts encoding synaptic scaffold Homer1 and cyclin-dependent kinase Cdk5 (2-tailed unpaired $t$ test, Homer1, $P<0.001 ; C d k 5, P<0.02$; 
Gria1, $P<0.26$; Grin2a, $P<0.61$; Grin2b, $P<0.02$; CaMKII $\alpha, P<0.34$; Figure 5A). Homer1 and Cdk5 are implicated in memory consolidation, and both proteins function in a common pathway regulating the localization and function of type I mGluRs, so we further investigated the role of HOMER1 and mGluR signaling in Sin3aNH animals $(4,28)$. Two classes of HOMER1 isoforms modulate mGluR signaling at the synapse (29). Long Homer1 isoforms promote mGluR signaling and recruit mGluRs to the postsynaptic density (PSD) (30-32). Short isoforms of Homer1 act in a dominant-negative manner to uncouple mGluRs from the PSD and from downstream effector molecules (33, 34). A more detailed examination of Homer1 mRNA expression in Sin3aNH animals revealed an increase in expression across the Homer1 locus, including regions specific to both short isoforms (Homerla-specific UTR following exon 5, and Ania-3-specific exon A) and long isoforms (exon 10) (2-tailed unpaired $t$ test; exon 1, $P<0.02$; Homer1a, $P<0.01$; Ania-3, $P<0.08$; exon 10, $P<0.01$; Figure $5 \mathrm{~B}$ and Supplemental Figure 2, A and E). To determine whether these gene-expression changes were induced by learning or were elevated by SIN3A depletion at baseline, we collected hippocampal tissue from $\mathrm{Sin} 3 \mathrm{aNH}$ mice and controls under home cage conditions to assay mRNA transcript levels. At baseline, we found no effect of genotype on the expression of Cdk5, Homerla, or Homer1 exons specific to short and long isoforms (2-tailed unpaired $t$ test; Cdk5, $P=0.2481$; Homer1a, $P=0.3819$; Homer1 exon 1, $P=0.8411$; Homer 1 exon $10, P=0.8636$; Figure 5 C). Because Homer1 is a regulatory target of both SIN3A and HDAC2 $(8,26,27)$ and because there is evidence that Homer1 transcription is regulated by histone acetylation (4), we used ChIP to identify DNA bound by SIN3A in hippocampal tissue, and we found that SIN3A binds to the Homer1 promoter just downstream of the transcription start site (Supplemental Figure 2C). These data provide evidence that SIN3A is a negative regulator of genes involved in synaptic structure and function, including Homer1, and suggest a molecular mechanism by which changes in synaptic Group I mGluR function may underlie behavioral and electrophysiological phenotypes in this model.

The Group I mGluRs (mGluR1 and mGluR5) play important roles in memory and synaptic plasticity (35-38) and are upstream of signaling pathways that contribute to plastic processes (Supplemental Figure 7A). In CA1 pyramidal neurons, mGluR1 and mGluR5 activation can induce PLC signaling and the release of calcium from intracellular stores, activation of PKC and ERK, activation of local dendritic translation, and potentiation of NMDAR-mediated currents (30, 39-45). As regulators of Group I mGluR localization, HOMER1 proteins are a key determinant of cellular processes including synaptic activity, signal transduction, and calcium signaling. Manipulations that increase levels of Homer1b/c or facilitate activation of mGluR5 have been shown to enhance performance in rodent learning paradigms (46-49). To determine whether changes in Homer1 expression by SIN3A lead to alterations in synaptic HOMER1 and mGluR localization, we collected hippocampal tissue from Sin3aNH mutant and WT littermates 1 hour after contextual fear conditioning and examined Group I mGluR and HOMER1 protein levels at the PSD. Levels of mGluR5 and long-form Homer1b/c protein, but not PSD-95, were significantly higher in the PSD of Sin $3 a N H$ mutant mice compared with controls (Figure 5D). Interestingly, Homer $1 b / c$ mRNA is upregulated in Sin3aNH hippocampal tissue, but Grm 5 mRNA is not (Supplemental Figure 2B), suggesting that increased recruitment of mGluR5 to the PSD may reflect a reorganization of existing receptors secondary to increased HOMER1B/C levels.

To test whether increased levels of synaptic Homer1/mGluR5 alters memory-related signaling cascades downstream of the Group I mGluRs, we assayed levels of ERK1/2 phosphorylation after contextual fear conditioning. ERK phosphorylation is essential for memory formation and synaptic plasticity $(19,50)$, is regulated by mGluR1 $\alpha / 5$ activity (30), and is necessary for Homer1/mGluR-mediated enhancement of LTP (51). We measured activation of ERK signaling pathways in hippocampal neurons 1 hour after contextual fear conditioning using immunostaining for phosphorylated ERK1/2 in sections from Sin3aNH and control mice (Figure 5E and Supplemental Figure 3). Quantification of the immunostained cells revealed a higher number of phospho-ERK1 $12^{+}$cells in area CA1 and the dentate gyrus (DG), but not in area CA3, of Sin3aNH mice compared with control littermates $(n=14$ for each group; CA1 [ $t$ test], $P=0.0163$; CA3 [ $t$ test $], P=0.5342$; DG [Mann-Whitney $U$ test], $P=0.0162$; Figure $5 \mathrm{~F}$ ). These results suggest that a reduction in neuronal Sin 3 a leads to elevated expression of the mGluR scaffold Homer1 and increased activity in mGluR signaling pathways.

Reduction of neuronal Sin3a changes mGluR contributions to LTP. The Group I mGluRs play roles in both synaptic potentiation and depression, via agonist-dependent and -independent signaling, and it has been shown that enhancing mGluR5 activation with positive allosteric modulators enhances LTP (48). 

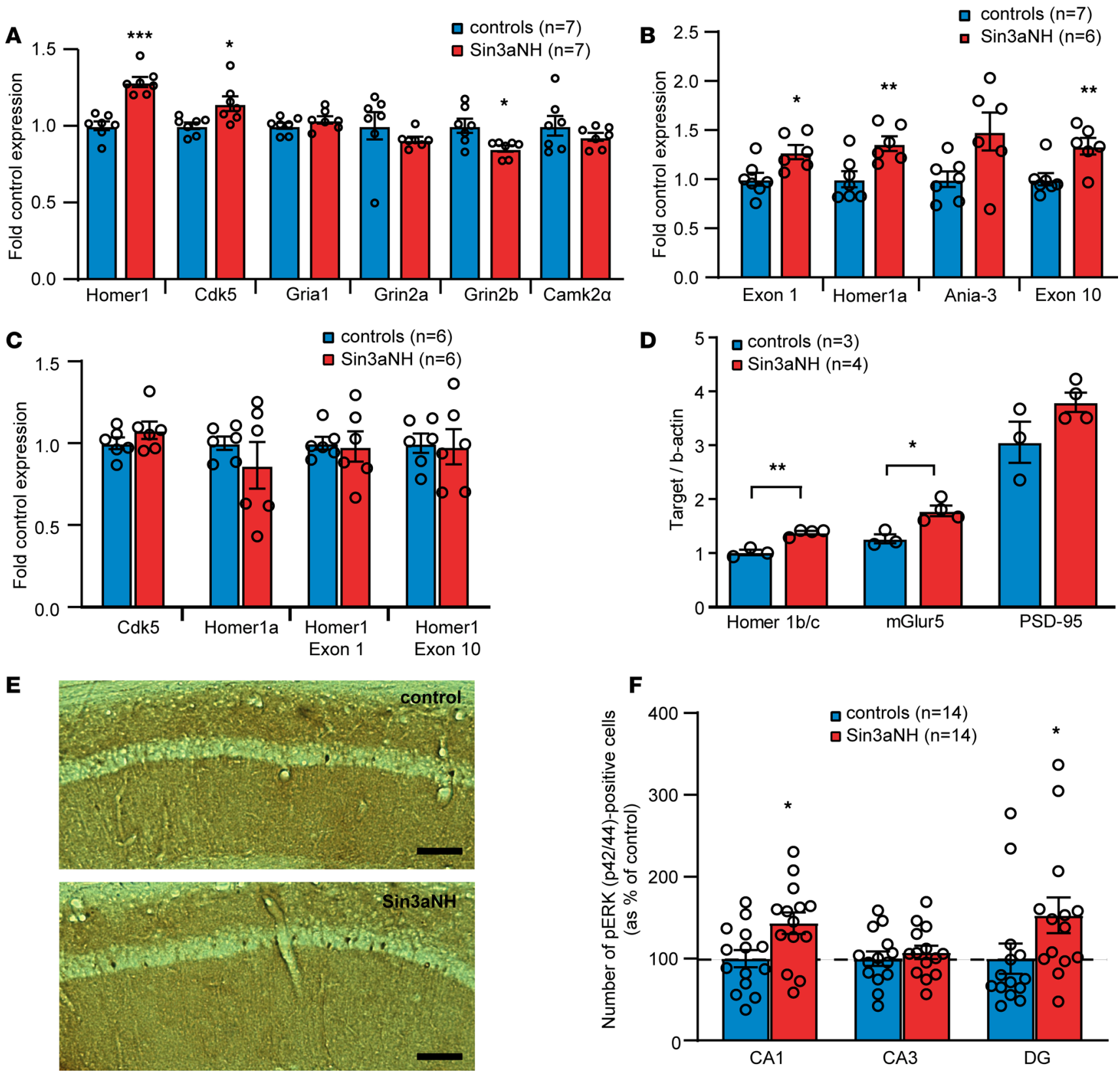

Figure 5. Reduction in SIN3A increases Homer1 expression and affects signaling cascades downstream of mGluR. (A) Expression of genes previously identified as regulatory targets of HDAC2 and SIN3A in hippocampus of WT and Sin3aNH mice 1 hour after fear conditioning. Levels of Homer1 (unpaired 2-tailed $t$ test, $n=7$ per group; $\left.\mathrm{t}_{[1,12]}=-6.448,{ }^{* * *} P<0.001\right)$ and $C d k 5\left(\mathrm{t}_{[1,12]}=-2.836,{ }^{*} P<0.02\right)$ are increased relative to controls, and the level of Grin2 $b$ is decreased $\left(t_{[112]}=3.038,{ }^{*} P<0.02\right)$. (B) Expression of Homer1 exons encoding both short (Homer1a) and long (containing exon 10) isoforms is elevated in Sin3aNH mice (control, $n=7$; $\operatorname{Sin} 3 a \mathrm{NH}, n=6$; unpaired 2-tailed $t$ test, exon $1 \mathrm{t}_{[1,11]}=-2.877$, ${ }^{*} P<0.02$; Homer1a, $\mathrm{t}_{[1,11]}=-3.313$, ${ }^{* *} P<0.01$; Ania-3, $\mathrm{t}_{[1,11]}=-2.146, P<0.08$; exon 10, $\left.\mathrm{t}_{[1,11]}=-3.251,{ }^{*} P<0.01\right)$. (C) Expression of Cdk5 and Homer1 is not affected at baseline by Sin3a depletion (control, $n=6$; Sin3aNH, $n=6$; unpaired 2-tailed $t$ tests; $C d k 5 \mathrm{t}_{[110]}=1.227, P=0.2481$; Homer1a $\mathrm{t}_{[110]}=0.9146, P=0.3819 ;$ Homer1 exon 1 $\mathrm{t}_{[1,10]}=0.2058, P=0.8411$; Homer1 exon 10, $\left.\mathrm{t}_{[1,10]}=0.1763, P=0.8639\right)$. (D) PSD protein levels of HOMER1B/C and mGluR5 are increased in Sin3aNH hippocampal PSD fractions compared with controls (control, $n=3$; $\operatorname{Sin} 3 a \mathrm{NH}, n=4$; unpaired 2-tailed $t$ test with Welch's correction; Homer1b/c, $t_{[1,3]}$ $=6.388,{ }^{*} P<0.008$; mGluR5, $\mathrm{t}_{[1,3]}=4.059,{ }^{*} P<0.016$; PSD-95, $\left.\mathrm{t}_{[1,3]}=1.756, P=0.182\right)$. (E) Representative images of hippocampal area CA1 showing cells stained for somatic ERK p42/44 in a Sin3aNH mouse and a control littermate 1 hour after contextual fear conditioning. Scale bar: $0.1 \mathrm{~mm}$. Larger images of all hippocampal subregions are in Supplemental Figure 5. (F) Quantification of pERK+ neurons in dorsal hippocampus following contextual fear conditioning shows a significantly higher number of cells positive for ERK p42/44 in CA1 and DG, but not CA3, of Sin3aNH mice compared with control littermates ( $n=14$ per group; unpaired 2-tailed $t$ test; CA1, ${ }^{*} P=0.0163 ; \mathrm{CA} 3, P=0.5342 ;$ Mann-Whitney $U$ test; DG, ${ }^{*} P=$ $0.0162)$. All data are presented as mean \pm SEM. 
A
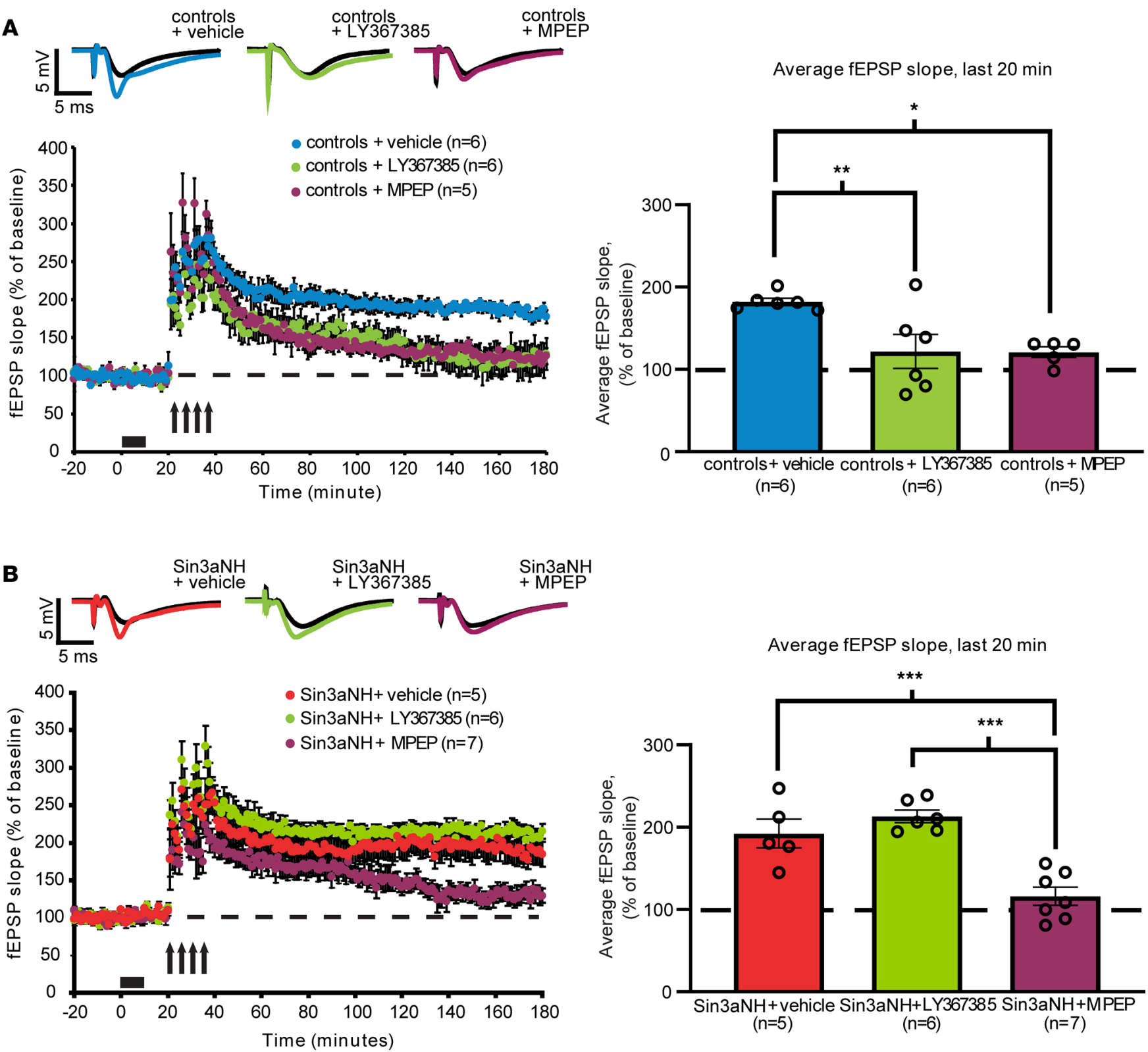

Figure 6. The role of mGluR signaling in hippocampal LTP is altered in Sin3aNH mice. (A) In control animals, LTP induced by 4 spaced trains of stimulation is impaired by the administration of the mGluR1 $\alpha$ antagonist LY367385 or the mGluR5 antagonist (controls + veh, $n=6$; avg. fEPSP slope $=182.24 \%$ $\pm 4.67 \%$; controls + LY367385, $n=5$; avg. fEPSP slope $=121.82 \% \pm 20.67 \%$; controls + MPEP, $n=5$; avg. fEPSP slope $=120.96 \% \pm 6.56 \% ; 2$-way repeated measures ANOVA, genotype, $\mathrm{F}_{[1,28]}=17.894, P=0.00023$; treatment, $\mathrm{F}_{[2,28]}=20.453, P=0.000003$; genotype $\times$ treatment interaction, $\mathrm{F}_{[2,28]}=7.924, P=$ 0.0019; Tukey's post hoc test, controls + vehicle vs. controls + MPEP, ${ }^{*} P=0.018$; controls + vehicle vs. controls + LY367385, $\left.{ }^{* *} P=0.008\right)$. $(B) \ln \operatorname{Sin} 3 a N H$ slices, application of an mGluR5 antagonist impairs spaced 4-train LTP, while antagonizing mGluR1 $\alpha$ has no effect (Sin3aNH + veh, $n=5$; avg. fEPSP slope $=192.29 \% \pm 17.4 \%$; Sin3aNH + LY367385, $n=6$; avg. fEPSP slope $=213.12 \% \pm 7.62 \%$; Sin3aNH + MPEP, $n=7$; avg. fEPSP slope $=116.06 \% \pm 10.94 \%$; Tukey's post hoc test; Sin3aNH + vehicle vs. Sin3aNH + MPEP, ${ }^{* *} P=0.0002 ; \operatorname{Sin} 3 a N H+$ vehicle vs. Sin3aNH + LY367385, $P=0.999 ; \operatorname{Sin} 3 a N H+L Y 367385$ vs. Sin3aNH + MPEP, $\left.{ }^{* * *} P=0.0002\right)$. All data are presented as mean \pm SEM.

Long- and short-isoform Homer1 interact with an intracellular domain of mGluR1/5 and differentially modulate signaling through downstream effectors (52). CDK5 phosphorylates the Homer1-binding domain of mGluR5, increasing its affinity for HOMER1 and altering its trafficking and association within the PSD (28). Changes in Homer1 expression have been linked to changes in synaptic plasticity, and previous studies have shown that increasing expression of long-form HOMER1 protein alters signaling through mGluR1 $\alpha /$ mGluR5 in long-lasting forms of synaptic plasticity $(49,53)$. Late-phase LTP in hippocampal slices from WT mice requires activity of both mGluR1 and mGluR5, but slices overexpressing 
long isoform Homer1c exhibited a form of LTP that did not require mGluR1 signaling but still depended on mGluR5, through a mechanism that is not entirely clear (53). To investigate whether the changes we observed in Homer1 expression in Sin $3 \mathrm{aNH}$ mice similarly affect the contributions of mGluR1 $\alpha$ and mGluR5 to synaptic plasticity, we induced late-phase LTP (L-LTP) using spaced 4-train stimulation in the presence of either the mGluR1 $\alpha$ antagonist LY367385 or the mGluR5 selective inverse agonist MPEP (35). When slices from WT mice and Sin $3 \mathrm{aNH}$ mice were stimulated with this protocol in the absence of drug treatment, no differences in LTP were observed, indicating that L-LTP maintenance is not changed by $\operatorname{Sin} 3 a$ depletion (Supplemental Figure 4). In control mice, antagonizing either of the type I mGluRs reduced LTP compared with vehicle-treated slices (controls + vehicle, $n=6$; controls + LY367385, $n=$ 5 ; controls + MPEP, $n=5$; 2 -way repeated measures ANOVA; genotype, $\mathrm{F}_{[1,28]}=17.894, P<0.001$; treatment, $\mathrm{F}_{[2,28]}=20.453, P<0.001$; genotype $\times$ treatment interaction, $\mathrm{F}_{[2,28]}=7.924, P=0.0019$; Tukey's post hoc test, controls + vehicle vs. controls + MPEP, $P=0.018$; controls + vehicle vs. controls + LY367385, $P=0.008$; Figure 6A). In slices from $\operatorname{Sin} 3 \mathrm{aNH}$ mice, administration of MPEP significantly reduced LTP, while antagonism of mGluR1 $\alpha$ with LY367385 did not have a significant effect on potentiation (Sin $3 a \mathrm{NH}$ + vehicle, $n=5 ; \operatorname{Sin} 3 \mathrm{aNH}+\mathrm{LY} 367385, n=6 ; \operatorname{Sin} 3 \mathrm{aNH}+\mathrm{MPEP}, n=7$; Tukey's post hoc test; Sin $3 \mathrm{aNH}$ + vehicle vs. Sin $3 \mathrm{aNH}+\mathrm{MPEP}, P=0.0002 ; \operatorname{Sin} 3 \mathrm{aNH}+$ vehicle vs. Sin $3 \mathrm{aNH}+\mathrm{LY} 367385, P=0.999$ $\operatorname{Sin} 3 \mathrm{aNH}+\mathrm{LY} 367385$ vs. Sin $3 \mathrm{aNH}+\mathrm{MPEP}, P=0.0002$; Figure $6 \mathrm{~B})$. These results indicate that LTP in $\mathrm{Sin} 3 \mathrm{aNH}$ mice is independent of mGluR1 $\alpha$ but requires mGluR5, suggesting that increased long Homer1 levels result in very specific changes in the function of the Group I mGluRs at CA1 synapses.

Enhanced mGluR5 signaling in CA1 pyramidal neurons of Sin3aNH mutant mice. Biochemical approaches to probing functional differences in mGluR1 and mGluR5 signaling are difficult to interpret due both to shared mechanisms and the issue of cellular heterogeneity in the region of interest. One way to functionally distinguish between these receptors is by measuring the conversion of the afterhyperpolarization (AHP) that follows a burst of spikes into an afterdepolarization (ADP) that occurs with Group I mGluR activation by (S)-3,5-Dihydroxyphenylglycine (DHPG) $(54,55)$. This AHP-to-ADP conversion requires G-protein signaling, the release of calcium from intracellular stores, PLC activation, and the activation of $\mathrm{Ca}_{\mathrm{v}} 2.3$ R-type voltage-gated calcium channels, and it is almost entirely mediated by mGluR5 (54), providing a clear functional differentiation between the Group I mGluRs that could be tested in Sin 3 aNH mice.

In acute hippocampal slices, we used whole-cell current-clamp recording to measure modulation of the postburst membrane potential by DHPG in CA1 pyramidal neurons as a readout of Group I mGluR function. Using C57BL/6J mice, we found that modulation was similar to that previously observed in rat neurons (54). Specifically, 15 minutes of perfusion with the mGluR1/5 agonist DHPG converted the medium AHP to an ADP in CA1 neurons, significantly changing the postburst membrane potential when compared with vehicle-treated cells (2-tailed $t$ test, $P=0.0298$, at 15 minutes; Supplemental Figure 5). CA1 pyramidal cells from controls and $\operatorname{Sin} 3 \mathrm{aNH}$ mice exhibited a postburst AHP of similar amplitudes prior to treatment with DHPG (controls, $n=7$, AHP $=-2.201 \pm 0.369 \mathrm{mV}$; Sin3aNH, $n=$ $5, \mathrm{AHP}=-2.482 \pm 0.450$; unpaired 2-tailed $t$ test, $P=0.638$; Figure 7, A and B). In Sin3aNH WT controls, CA1 pyramidal neurons exhibited a similar postburst ADP in response to DHPG administration, while in cells from $\operatorname{Sin} 3 \mathrm{aNH}$ mutants, the measured change in the postburst potential was significantly greater than in controls. Coapplication of the mGluR5 inverse agonist MPEP with DHPG almost completely blocked the appearance of the postburst ADP in both controls and Sin3aNH mutants (controls + DHPG, $n=7$ cells, $\Delta \mathrm{V}=2.43 \pm 0.66 \mathrm{mV}$; Sin3aNH + DHPG, $n=5$ cells, $\Delta \mathrm{V}=7.49 \pm 0.84 \mathrm{mV}$; controls + DHPG + MPEP, $n=4$ cells, $\Delta \mathrm{V}=0.07 \pm 0.44 \mathrm{mV}$; Sin $3 \mathrm{aNH}+\mathrm{DHPG}+\mathrm{MPEP}, n=5$ cells, $\Delta \mathrm{V}=1.05 \pm 0.52 \mathrm{mV}$; 2-way ANOVA; genotype, $\mathrm{F}_{[1,17]}=19.40 P=0.0004 ;$ drug, $\mathrm{F}_{[1,17]}=41.27, P<$ 0.0001; genotype $\times$ drug, $\mathrm{F}_{[1,17]}=8.848, P=0.0085$; Holm-Sidak's multiple comparisons test; control + DHPG vs. Sin 3 aNH + DHPG, $P=0.0001 ; \operatorname{Sin} 3 a N H+$ DHPG vs. Sin 3 aNH + DHPG + MPEP, $P$ $<0.0001$; control + DHPG + MPEP vs. Sin3aNH + DHPG, $P<0.0001$; control + DHPG vs. control + DHPG + MPEP, $P=0.0742$; Figure 7C). Basic properties of resistance and excitability were also compared between $\operatorname{Sin} 3 \mathrm{aNH}$ mutants and controls. Input resistance in CA1 pyramidal neurons from Sin $3 \mathrm{aNH}$ mice and control littermates was found to be similar (controls, $n=23$ cells; Sin $3 \mathrm{aNH}, n=24$ cells; unpaired 2-tailed $t$ test; $P=0.838$; Supplemental Figure 6A). Assaying excitability using step current injections $(500 \mathrm{~ms}$ duration, $+300 \mathrm{pA}$ ) revealed that neurons from $\mathrm{Sin} 3 \mathrm{aNH}$ animals and control littermates exhibited similar rates of action potential firing (controls, $n=10$ cells; Sin $3 \mathrm{aNH}, n=9$ cells; unpaired 2-tailed $t$ test, $P=0.068$; Supplemental Figure 6B.) 
controls, $12 \mu \mathrm{M}$ DHPG ( $n=7$ cells)

\section{A}

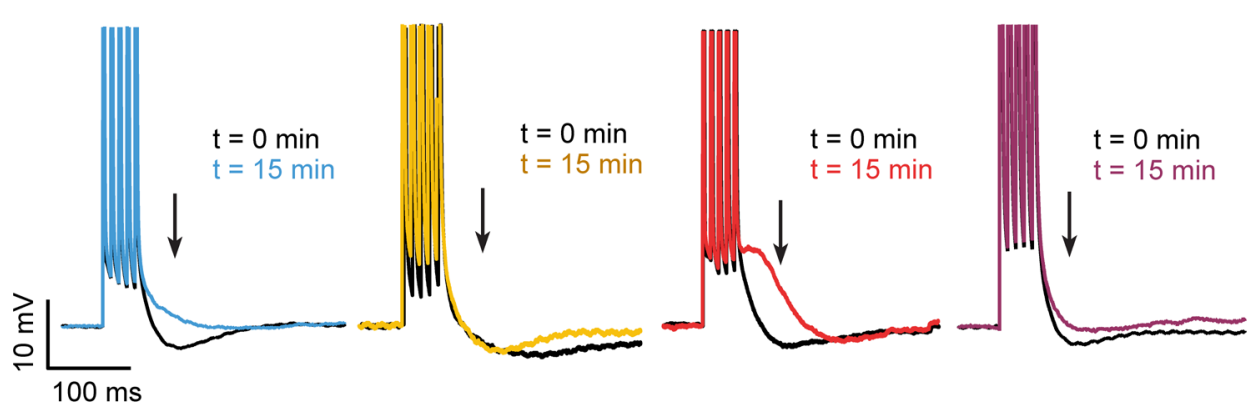

Sin3aNH, $12 \mu \mathrm{M}$ DHPG $(n=5$ cells $)$ controls, 12
$(n=4$ cells $)$
$\operatorname{Sin} 3 a N H, 12 \mu M$ DHPG $+10 \mu M$ MPEP ( $n=5$ cells $)$
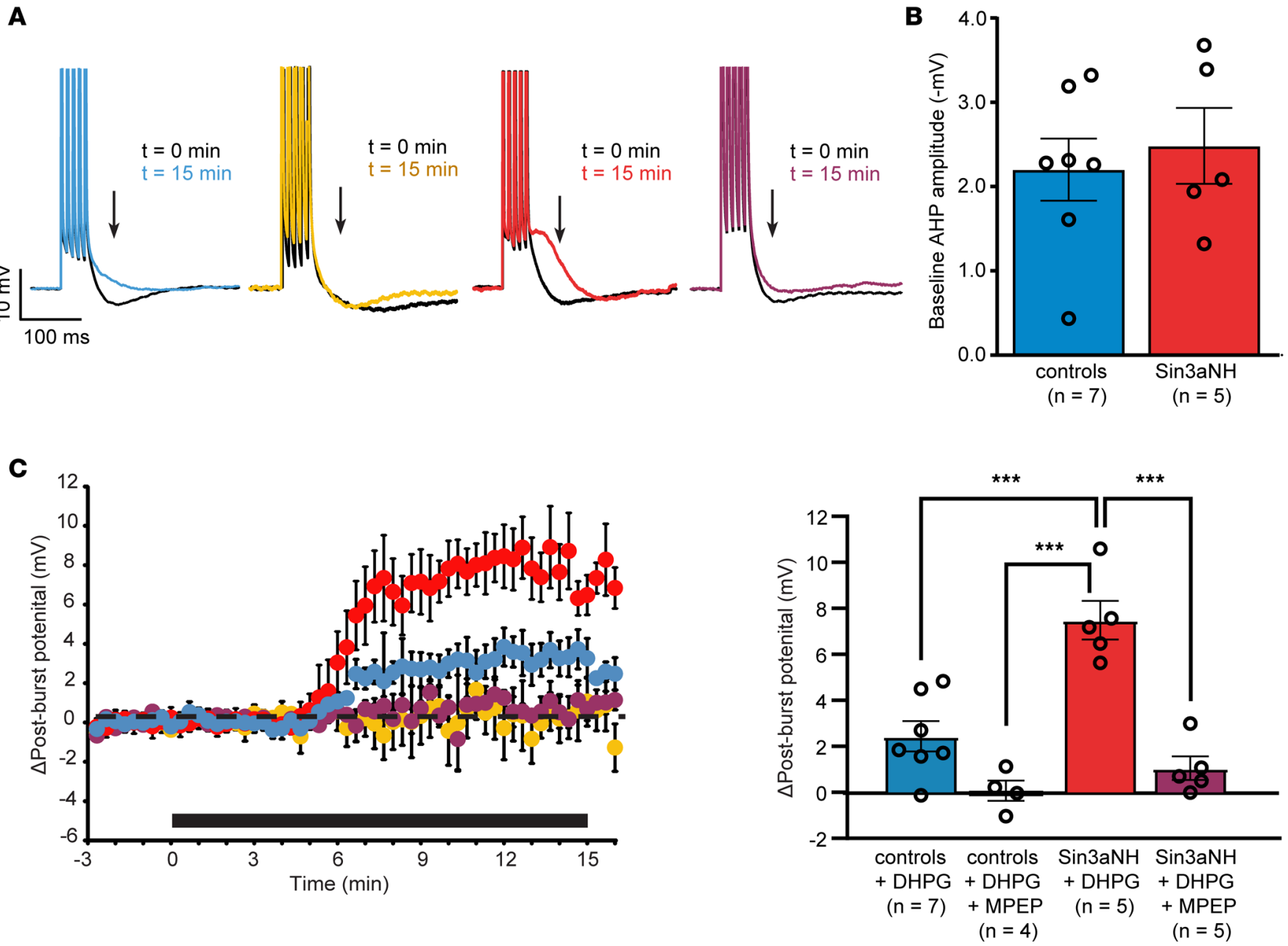

Figure 7. The DHPG-mediated postburst afterdepolarization is enhanced in CA1 pyramidal neurons of Sin3aNH mice. (A) Example traces showing postburst behavior of CA1 pyramidal neurons before drug treatment (black, all genotypes) and after 15 minutes of drug exposure (controls, blue; Sin3aNH, red) or DHPG + MPEP (controls, yellow; Sin3aNH, purple). (B) The mean amplitude of the baseline postburst afterhyperpolarization in CA1 neurons did not differ between control and Sin3aNH animals prior to DHPG treatment (controls, $n=7$; AHP amplitude $=-2.201 \pm 0.369 \mathrm{mV}$; Sin3aNH $n=5$; amplitude $=-2.482 \pm 0.450 \mathrm{mV}$; unpaired 2-tailed $t$ test, $P=0.638)$. (C) The DHPG-mediated AHP-to-ADP conversion is enhanced in Sin3aNH mice relative to controls, following 15 minutes of drug exposure. The mGluR5 inhibitor MPEP $(10 \mu \mathrm{M})$ blocks the AHP-to-ADP conversion in Sin3aNH mice when coapplied with $12 \mu \mathrm{M}$ DHPG (controls + DHPG, $n=7$ cells; $\Delta \mathrm{V}=2.43 \pm 0.66 \mathrm{mV}$; Sin3aNH + DHPG, $n=5$ cells; $\Delta \mathrm{V}=7.49 \pm 0.84 \mathrm{mV}$; controls + DHPG + MPEP, $n=4$ cells; $\Delta \mathrm{V}=0.07 \pm 0.44 \mathrm{mV}$; Sin3aNH + DHPG + MPEP, $n=5$ cells; $\Delta \mathrm{V}=1.05 \pm 0.52 \mathrm{mV} ; 2$-way ANOVA, genotype, $\mathrm{F}_{[1,17]}=19.40$, $P=0.0004$; drug, $F_{[1,17]}=41.27, P<0.0001$; genotype $\times$ drug, $F_{[1.17]}=8.848, P=0.0085$; Holm-Sidak's multiple comparisons test, control $+D H P G$ vs. $\operatorname{Sin} 3 a N H+D H P G,{ }^{* * *} P=0.0001 ; \operatorname{Sin} 3 a N H+D H P G$ vs. Sin3aNH + DHPG + MPEP, ${ }^{* * *} P<0.0001 ;$ control + DHPG + MPEP vs. Sin3aNH + DHPG, ${ }^{* * * P}<$ 0.0001; control + DHPG vs. control + DHPG + MPEP, $P=0.0742)$. Representative traces are shown before $(\mathrm{t}=0 \mathrm{~min})$ and after $(\mathrm{t}=15 \mathrm{~min}) \mathrm{drug}$ treatment. Black bar indicates time course of drug treatment (12 $\mu \mathrm{M}$ DHPG or $12 \mu \mathrm{M}$ DHPG $+10 \mu \mathrm{M} \mathrm{MPEP})$. All data are presented as mean \pm SEM.

In summary, these results indicate that, in CA1 pyramidal neurons of mice, activation of metabotropic glutamatergic receptors (in particular, mGluR5) modulates excitability through the conversion of the postburst AHP into an ADP. Consistent with an enhancement in mGluR5/Homer1 signaling, Sin $3 \mathrm{aNH}$ mutant mice exhibited significantly increased ADP amplitude in response to mGluR activation. The enhanced effects of DHPG in Sin3aNH mice, as well as its attenuation by MPEP, supports the hypothesis that upregulated expression of Homer1 and Cdk5 increases signaling through mGluR5. The AHP-to-ADP conversion modulates neuronal excitability and facilitates postsynaptic spiking $(54,56)$, which could, in turn, support enhanced memory and LTP in the Sin3aNH mice. 


\section{Discussion}

Inhibition of HDAC activity enhances memory and facilitates neuronal plasticity (1). However, the precise molecular mechanisms by which these manipulations ultimately affect synaptic and neuronal function are not understood, and the identification of functional effector genes targeted by HDAC inhibition has been challenging. We targeted the corepressor SIN3A, a scaffolding protein that coordinates a multifunctional corepressor complex containing several histone-modifying enzymes, including HDAC1 and HDAC2. Mice carrying a conditional neuronal depletion of $\operatorname{Sin} 3 a$ have reduced levels of SIN3A protein in hippocampus. This chronic reduction of SIN3A is accompanied by enhanced hippocampal synaptic plasticity and memory formation, mimicking the effects of acute HDAC inhibitor administration. These enhancements in memory and plasticity are accompanied by increased expression of several neuronal genes regulated by HDAC2 and SIN3A, including Homer1 and Cdk5. Although our data support a role for SIN3A in the regulation of Homer1 transcription (Figure 5 and Supplemental Figure 2), further analysis of Homer 1 histone acetylation in Sin3aNH hippocampus would clarify the regulatory role of the SIN3A-HDAC complex, and it will still be necessary in the future to use isoform-specific antibodies to determine how Homer1 gene expression changes correlate with HOMER1 protein levels. Future investigations using an unbiased measurement of actively transcribed mRNA by a technique such as translating ribosome affinity purification (TRAP) $(57,58)$ would provide more complete information about expression changes in Sin3aNH hippocampus and facilitate comparison with transcription changes induced by HDAC inhibition or ablation.

In fear-conditioned Sin3aNH animals, we observed an increase in PSD protein levels of HOMER1B/C and mGluR5, and increased phosphorylation of ERK, which is a downstream target of Group I mGluRs. Alterations in Homer1 and mGluR functioning have profound effects on synaptic structure, plasticity, and cognition $(36,48,49,53)$. The upregulation of Homer1, increased synaptic levels of mGluR5 and HOMER1 protein, enhancement of mGluR5-mediated signaling in CA1 pyramidal neurons in Sin $3 \mathrm{aNH}$ mice, mGluR5-dependent AHP-to-ADP conversion, and the observed shift in the requirements for Group I mGluR signaling in Sin3aNH L-LTP indicate that the enhancements we observed in hippocampus-dependent memory and synaptic plasticity are likely attributable, in part, to changes in synaptic Homer1/ mGluR5 signaling and suggest a model by which these changes could occur. Long isoforms of Homer1 bind to the intracellular C-terminal tails of Group I mGluRs and link them to the PSD in dendritic spines $(31,32)$. Under baseline conditions both mGluR1 $\alpha$ and mGluR5 are linked to the PSD through interactions with long Homer1b/c (Supplemental Figure 7A). Group I mGluRs are associated with several key signaling pathways associated with memory/plasticity $(30,36,48)$, and under baseline conditions, the activation of both mGluR1 $\alpha$ and mGluR5 are necessary for LTP (35). In Sin3aNH mice, higher levels of long-form Homer1b/c are accompanied by increased localization of mGluR5 to the PSD (Figure 5D) and an enhanced mGluR5-mediated ADP (Figure 7). There is evidence that mGluR1 and mGluR5 interact as homodimers rather than forming heterodimers (59); a possible explanation is that increased Homer $1 b / \mathrm{c}$ expression leads to structural changes at the synapse that promote inclusion of mGluR5 and exclusion of mGluR1, leading to a shift in their necessity for LTP. Increased synaptic mGluR5 could reduce the requirement for mGluR1 $\alpha$ in activating shared downstream signaling pathways supporting maintenance of LTP, and this may in turn facilitate increased neuronal excitability and postsynaptic spiking (54). Higher levels of synaptic mGluR5 could also facilitate LTP enhancement via increases in $\left[\mathrm{Ca}^{2+}\right] \mathrm{i}(30,42,48)$, downstream signaling through PKC and $\operatorname{ERK}(30,42,48)$, and even NMDA receptor potentiation through Src kinase (42) (Supplemental Figure 7B). Another potential pathway by which Homer1/mGluR5 activation could enhance hippocampal plasticity and memory is through a mechanism similar to EPSP-spike potentiation; high-frequency stimulation at the CA3-CA1 synapses has been shown to enhance firing rate and improve temporal precision of spiking through the activation of synaptic mGluR5 and subsequent increase in persistent $\mathrm{Na}^{+}$currents in dendrites, even without the emergence of an ADP (60).

It is crucial to acknowledge that there is a wide-ranging network of interdependent synaptic signaling molecules upstream, downstream, and parallel to the Group I mGluRs that we have not investigated but could contribute substantially to the phenotypes observed in Sin3aNH mice. For example, while ERK is indeed a downstream target of mGluR1 $\alpha / 5$ signaling, the Group I mGluRs are can also be a substrate for ERK (61); furthermore, ERK is also downstream of numerous synaptic molecules, including NMDA receptors and regulators thereof such as Shank, GKAP, and SynGAP (62), all of which may be affected by changes to the PSD. Indeed, the activation of Src kinase downstream of mGluR5 could potentiate NMDAR signaling and associated signaling networks (42). While we utilized a candidate gene-driven approach to study the 
effects of $\operatorname{Sin} 3 a$ depletion as it relates to HDAC inhibition, which led us to a specific aspect of mGluR5 signaling and interaction with long-form HOMER1, there are other aspects of mGluR/Homer1 interaction that we did not explore in Sin3aNH mice but that should be investigated in future work, such as mGluR5-LTD, which is impacted by both HDAC inhibition (63) and Homer1b/c depletion (64), as well as agonist-independent signaling through mGluR1/5 induced by Homer1a. It will be both interesting and important to establish fully how Sin3a depletion alters Group I mGluR signaling and what state-specific changes are induced.

Pharmacological inhibition of HDAC enzymes could be an important component of future therapies for not only improving cognition, but also treating cognitive, neurodevelopmental, and neurodegenerative disorders $(2,65)$. One of the major obstacles to developing HDAC inhibitor drugs as neural therapeutic agents is a lack of understanding of basic molecular mechanisms driving the synaptic and behavioral effects of these compounds. Here, we show that neuronal depletion of the HDAC-coordinating corepressor SIN3A alters the expression of HDAC-regulated genes, leading to changes in Group I mGluR function and downstream signaling through ERK, and these effects on mGluR5/Homer1 signaling likely mediate the enhancements in memory and plasticity observed in Sin $3 \mathrm{aNH}$ mice. Indeed, it has recently been demonstrated that increasing mGluR signaling via positive allosteric modulators enhances hippocampal LTP, long-term depression, and long-term memory consolidation in rodents (48), while disruption of Group I mGluR function has been implicated in many cognitive and neurological disorders that may also be influenced by histone acetylation (including anxiety disorder, Fragile X syndrome, autism spectrum disorder, Parkinson's disease, and schizophrenia) $(41,66,67)$. There have been numerous hypotheses that glutamatergic signaling is altered in autism (68). Group I mGluRs are of special interest in this regard because mGluR gene mutations and altered levels of mGluR5 have been reported not only in individuals with autism (69-71), but also in individuals with Fragile $\mathrm{X}$ syndrome, an autism-related disorder with high coincidence of intellectual disability (72). The therapeutic potential of pharmacological modulators of mGluR5 have been tested in patients with Fragile X syndrome in several clinical trials with mixed results (73-75), but these trials have largely focused on emotional and behavioral endpoints rather than cognitive functioning. These findings provide evidence linking mGluR signaling at the synapse to epigenetic mechanisms regulating gene expression for the first time to our knowledge, paving the way for therapeutics to treat cognitive deficits.

\section{Methods}

\section{Mice}

Mutant mice with a forebrain-specific deletion of $\operatorname{Sin} 3 a$ were generated by crossing mice homozygous for a loxP-flanked exon 4 of the $\operatorname{Sin} 3 a$ gene $\left(\operatorname{Sin} 3 a^{L / L}\right)(76)$ with mice carrying the CaMKII $\alpha$-Cre transgene (L7ag\#13) (77) and heterozygous for a loxP-flanked exon 4 of $\operatorname{Sin} 3 a\left(C a M K I I \alpha-C r e ; ~ S i n 3 a^{+/ L}\right.$ ) to produce CaMKII $\alpha$-Cre; $\operatorname{Sin} 3 a^{L / L}(\operatorname{Sin} 3 \mathrm{aNH})$ mice and control littermates. Sin $3 a^{L / L}$ mice were a gift from Ronald DePinho (The University of Texas MD Anderson Cancer Center, Houston, Texas, USA). CaMKII-Cre (line L7ag\#13) mice were a gift from Ioannis Dragatsis (University of Tennessee, Memphis, Tennessee, USA). Deletion and premature stop codons were confirmed in cDNA from Sin3aNH hippocampus by PCR across the deletion site using the following primers: exon 2, forward, 5' - CAGCAGTTTCAGAGGCTCAAG - 3'; and exon 6, reverse, 5' - GGGCATACACCTCTTGCTCA - 3'. Amplified products were separated by gel electrophoresis, purified, and sequenced. All genotypes produced from this mating were examined in fear conditioning. No differences were observed among genotypes, with the exception of Sin $3 \mathrm{aNH}$ mice; therefore, all other genotypes were grouped for controls in the presented data. Experimenters were blind to the genotypes of the mice during collection of behavioral and electrophysiological data. CaMKII $\alpha$-Cre line L7ag\#13 expresses Cre recombinase throughout the forebrain, including the hippocampus, cortex, and amygdala, with the majority of recombination occurring postnatally (77). These Sin $3 \mathrm{aNH}$ mice were produced after more than 6 generations of backcrossing of the loxP-flanked Sin $3 a$ allele and more than 9 generations of backcrossing the CaMKII $\alpha$-Cre transgene into C57BL/6J. Both male and female WT and Sin3aNH mice were used for these biochemical, behavioral, and electrophysiological experiments. Because of the difficulties associated with the breeding of this strain of mice, these studies were not powered to detect sex differences, but sexes were balanced among groups to eliminate sex-driven biases in our conclusions.

Genotyping was performed using PCR with allele-specific primers. To identify mice bearing floxed alleles of the Sin $3 a$ gene, PCR was performed with the following primers: forward, $5^{\prime}$ - AGC CAG CCC TGA GAC TAG TGA TAA AC - 3'; reverse, 5' - GGG GGA ATG CTG TGT TTT AGG TAT G - 3'. 
PCR reactions were performed using RedExtract-N-Amp (MilliporeSigma, R4775) with the following thermal cycles parameters: $94^{\circ} \mathrm{C}$ for 15 minutes, $\left(94^{\circ} \mathrm{C}\right.$ for 30 seconds, $55^{\circ} \mathrm{C}$ for 30 seconds, $72^{\circ} \mathrm{C}$ for 30 seconds) $\times 50$ cycles, $72^{\circ} \mathrm{C}$ for 10 minutes. For CaMKII-Cre genotyping, PCR was performed with the following primers: Cre1 5' - CTG CCA CGA CCA AGT GAC AGC - 3', Cre2 5' - CTT CTC TAC ACC TGC GGT GCT - 3', Bglob1 5' - CCA ATC TCC TCA CAC AGG ATA GAG AGG GCA GG - 3', Bglob2 5' - CCT TGA GGC TGT CCA AGT GAT TCA GGC CAT CG - 3'. Thermal cycling parameters were as follows: $94^{\circ} \mathrm{C}$ for 3 minutes, $\left(94^{\circ} \mathrm{C}\right.$ for 45 seconds, $61^{\circ} \mathrm{C}$ for 45 seconds, $72^{\circ} \mathrm{C}$ for 60 seconds] $\times 30$ cycles, $72^{\circ} \mathrm{C}$ for 10 minutes.

Mice were maintained under standard conditions consistent with NIH guidelines for animal care and use and were approved by the IACUC of the University of Pennsylvania. Mice were maintained on a 12-hour light-dark cycle and provided with food and water in their home cages ad libitum. Animals were group housed in cages of 2-5 littermates, except for fear-conditioning experiments. For fear conditioning, animals were moved from group housing to single housing 1 week prior to training. Behavioral testing, tissue collection, and electrophysiology were conducted on 2- to 6-month-old male and female animals during the light portion of the cycle.

\section{Immunoblots}

Hippocampal lysation and immunoblotting were conducted as previously described (78). Mice were cervically dislocated, and hippocampi were quickly dissected and flash frozen on dry ice. Hippocampi were homogenized at $4^{\circ} \mathrm{C}$ in $500 \mu \mathrm{L}$ of cell lysis solution (10 mM HEPES, pH 7.9, $1 \mathrm{mM}$ EDTA, $1.5 \mathrm{mM}$ $\mathrm{MgCl}_{2}, 10 \mathrm{mM} \mathrm{KCl}, 1 \%$ protease inhibitor cocktail [MilliporeSigma], $1 \mathrm{mM} \mathrm{DTT}$ ), and nuclei were pelleted by 20 -minute centrifugation at $1000 \mathrm{~g}$ at $4^{\circ} \mathrm{C}$. Nuclear pellets were resuspended in $100 \mu \mathrm{L}$ of nuclear lysis buffer (20 mM HEPES, pH 7.9, 0.2 mM EDTA, $1.5 \mathrm{mM} \mathrm{MgCl}_{2}, 400 \mathrm{mM} \mathrm{KCl,} \mathrm{25 \%} \mathrm{glycerol,} \mathrm{1 \%}$ protease inhibitor cocktail [MilliporeSigma], $1 \mathrm{mM}$ DTT). After 30-minute incubation on ice, samples were centrifuged at $4^{\circ} \mathrm{C}$ for 20 minutes at $1000 \mathrm{~g}$. Protein concentrations of the supernatants were quantified by the Bradford method (Bio-Rad). Nuclear protein samples were prepared using $20 \mu \mathrm{g}$ fractionated protein combined with NuPage LDS sample buffer and 2-mercaptoethanol (Invitrogen) and incubated for 5 minutes at $100^{\circ} \mathrm{C}$. Proteins were separated on a 3-8\% Bis-Tris gel (Novex, Invitrogen) for 1 hour and transferred to a PVDF membrane for immunoblotting. Membrane was blocked with 5\% milk/PBST for 2 hours at room temperature (RT) and incubated with anti-SIN3A (MilliporeSigma, S6695) 1:500 in 2\% milk/PBST at $4^{\circ} \mathrm{C}$ overnight. The membrane was washed 3 times in PBST for 10 minutes and incubated with anti-rabbit HRP conjugated secondary antibody (Santa Cruz Biotechnology Inc., sc-2004) 1:1000 in 2\% milk/PBST for 2 hours at RT. After three 10-minute washes in PBST (Thermo Fisher Scientific), the membrane was incubated for 1 minute in ECL Western Blotting Detection Reagent (GE Healthcare) and developed on film. For detection of $\beta$ tubulin control band, antibody was removed from the blot using Restore Western Blot Stripping Buffer (Thermo Fisher Scientific) according to the manufacturer's instructions. The membrane was reblocked and reprobed with anti- $\beta$ tubulin antibody (MilliporeSigma, T4026) using the same blotting protocol.

\section{Gene expression}

Hippocampal RNA was purified and cDNA was prepared as previously described (78). Following contextual conditioning, hippocampal dissections were performed on ice, and tissue was stored in RNA Later (Qiagen) at $-80^{\circ} \mathrm{C}$ until RNA extraction. RNA was isolated by Trizol extraction and purified using an RNeasy kit (Qiagen) according to the manufacturer's instructions. RNA concentration was measured using a NanoDrop spectrophotometer (Thermo Fisher Scientific). Template cDNA was synthesized from $1 \mu \mathrm{g}$ total RNA using the RETROscript kit with oligo(dT) primers (Ambion). Reactions were conducted at $44^{\circ} \mathrm{C}$ for 1 hour and heat inactivated at $100^{\circ} \mathrm{C}$ for 10 minutes, and the final products were diluted in water to a final concentration of $2 \mathrm{ng} / \mu \mathrm{L}$. qPCR was performed on the Viia7 Real Time PCR platform (Applied Biosystems) in $5 \mu \mathrm{L}$ reactions consisting of $4.5 \mathrm{ng}$ cDNA, $2.5 \mu \mathrm{L}$ Fast SYBR Green master mix (Applied Biosystems), and $250 \mathrm{nM}$ forward and reverse primers. Samples that did not amplify were excluded from analysis. Values were normalized to 3 housekeeper genes (Gapdh, ActB, ActG), and relative quantification was calculated using a $\Delta \Delta \mathrm{Ct}$ method as described previously (6). Relative gene expression is reported as the fold difference in mean values for distinct biological replicates. 


\section{Behavior}

Fear conditioning was conducted as previously described (78). For contextual conditioning, naive 2- to 6-month old male and female Sin3a NH (CaMKII $\alpha$-Cre; Sin $\left.3 a^{L / L}\right)$ and control (CaMKII $\alpha$-Cre; $\operatorname{Sin} 3 a^{L /+}$ and $\operatorname{Sin} 3 a^{L / L}$ ) mice were placed in a training chamber for 180 seconds and a single, 2 -second, $0.75 \mathrm{~mA}$ foot shock was administered after 148 seconds. Contextual fear testing was conducted 1 hour or 24 hours after training, by reexposing the animals to the trained context for 5 minutes. Cued fear conditioning was conducted using a similar training procedure as contextual fear, with the addition of a 30 -second tone presentation starting at 120 seconds. Cued fear testing was conducted in a potentially novel conditioning chamber with altered floor covering, odor, and dimensions. Mice were exposed to the context for 3 minutes, followed immediately by 3 minutes of tone presentation. Freezing behavior during contextual and cued testing was scored by computer using FreezeScan software (Clever Systems). Freezing levels for all groups was examined for normality using the Shapiro-Wilk test. Normally distributed data sets were compared using 2-way ANOVA, with significance levels of $P<0.05$. Nonparametric data were compared using independent samples Kruskal-Wallis test, with $P$ value significance level of 0.05 . For all conditioning experiments, animals with responses 2 SDs above or below the group mean were excluded from the analysis as outliers. Mice were tested in the elevated zero maze with a single, 5-minute exposure in which the animals were allowed to freely explore the maze. Time spent in open and closed quadrants of the maze were scored manually by a trained observer blind to the genotypes of the animals. A 2-tailed independent samples $t$ test was used to compare genotypes for open and closed areas. For all behavioral tasks, testing order was designed so that mice of different sexes were not in the testing room at the same time. Testing chambers were thoroughly cleaned between each session to minimize odor cues.

\section{Subcellular fractionation and semiquantitative Western blotting}

Subcellular fractionation was conducted for the hippocampus of Sin $3 \mathrm{a} \mathrm{NH}$ and control mice following the protocol as previously described $(79,80)$. Briefly, $20-30 \mathrm{mg}$ hippocampal tissue from male mice were homogenized in $25 \mathrm{mM}$ Tris- $\mathrm{HCl}, \mathrm{pH} 7.4$, containing $320 \mathrm{mM}$ sucrose, $0.5 \mathrm{mM}$ EDTA, and $0.5 \mathrm{mM}$ EGTA in presence of protease and phosphatase inhibitor cocktails (MilliporeSigma). The homogenates were centrifuged at $800 \mathrm{~g}$, and the supernatant was centrifuged at 19,200 $\mathrm{g}$. The pellets containing crude synaptosomal membranes were suspended in $25 \mathrm{mM}$ Tris-HCL, $\mathrm{pH} 7.4$, containing $0.5 \mathrm{mM}$ EDTA, 0.5 mM EGTA, and protease and phosphatase inhibitors. Two thirds of the synaptosomal membranes were precipitated in $1 \%$ Triton-X buffer for 1.5 hours at $4^{\circ} \mathrm{C}$ to obtain fractions enriched for the PSD. Synaptosomal membrane (P2) and PSD fractions were size fractionated in 7.5\% Tris Glycine (Bio-Rad) gels and examined by Western blotting with the antibodies for Homer1 (anti-mouse, Santa Cruz Biotechnology Inc., sc-136358), mGlur5 (anti-goat, Santa Cruz Biotechnology Inc., sc-47147), PSD-95 (anti-mouse, Neuro Mab, 75-028), and $\beta$-actin (anti-mouse, MilliporeSigma, A2228). The quantified band intensities were analyzed and plotted using the Graph Pad Prism software; all data were expressed as mean \pm SEM. Students' $t$ test, unpaired and 2-tailed, was used for between-group comparisons.

IHC

Transcardial perfusions and immunohistochemical staining were conducted as previously described (17). Sections were incubated with rabbit anti-phopsho-ERK1/2 (Cell Signaling Technology, AB9101). Phosphatase inhibitors were included in the fixative and in all buffers (17). Cell counts were conducted as described (17) by a trained observer blind to grouping. Groups were compared using a 2-tailed independent samples $t$ test or Mann-Whitney $U$ test as appropriate.

\section{Electrophysiology}

Field recordings. To assess the effects of conditional Sin3a mutation on LTP, 2- to 6-month old male and female mice were killed by cervical dislocation, and their hippocampi were quickly dissected out into icecold oxygenated artificial CSF (artificial cerebrospinal fluid [aCSF]; $124 \mathrm{mM} \mathrm{NaCl}, 4.4 \mathrm{mM} \mathrm{KCl}, 1.3 \mathrm{mM}$ $\mathrm{MgSO}_{4} \cdot 7 \mathrm{H}_{2} \mathrm{O}, 1 \mathrm{mM} \mathrm{NaH} \mathrm{PO}_{4} \cdot \mathrm{H}_{2} \mathrm{O}, 26.2 \mathrm{mM} \mathrm{NaHCO}_{3}, 2.5 \mathrm{mM} \mathrm{CaCl}_{2} \cdot 2 \mathrm{H}_{2} \mathrm{O}$, and $10 \mathrm{mM}$ D-glucose). Transverse hippocampal slices were cut $400-\mu \mathrm{m}$ thick using a tissue chopper (Stoelting Co.), placed in an interface chamber, and perfused with oxygenated $\mathrm{aCSF}$ at $28^{\circ} \mathrm{C}$ at a flow rate of $1 \mathrm{~mL} / \mathrm{min}$. Slices were allowed to recover for at least 2 hours before beginning electrophysiological recordings. Single-pathway recordings were made using a single bipolar stimulating electrode made from nichrome wire (A-M Systems) 
placed in the stratum radiatum, and used to elicit action potentials in the axons of CA3 pyramidal neurons. Field excitatory postsynaptic potentials (fEPSPs) were recorded using an aCSF-filled glass microelectrode (A-M Systems) with a resistance between 1 and $5 \mathrm{M} \Omega$ placed in the stratum radiatum region of CA1. Data collection was handled by Clampex software (Molecular Devices) and was analyzed using Clampfit software (Molecular Devices). The peak fEPSP amplitude induced by the stimulating electrode was required to be at least $5 \mathrm{mV}$, and stimulus intensity during the recording was set to produce a response of $40 \%$ of the maximum fEPSP amplitude. Test stimulation occurred once every minute. Baseline responses were recorded for 20 minutes before LTP induction or drug application. To examine early-phase LTP (E-LTP), one 1-second, $100 \mathrm{~Hz}$ train of stimuli was applied through the stimulating electrode. To examine L-LTP, four 1-second, 100 $\mathrm{Hz}$ trains of stimuli were delivered 5 minutes apart. Recordings continued for at least 160 minutes after LTP induction. The initial slope of the recorded fEPSPs were normalized to the average of the 20 baseline traces and expressed as percentages of this baseline value.

Single-cell recordings. Slices were prepared as previously described $(54,55)$. Briefly, near-horizontal slices (300 $\mu \mathrm{m}$ thick) were prepared from P21-P30 brains, using a vibrating tissue slicer (Microm HM $650 \mathrm{~V}$ Vibration microtome, Thermo Fisher Scientific). Animals were anesthetized with isofluorane and decapitated, and the brain was rapidly removed and placed in ice-cold sucrose slicing solution containing (in $\mathrm{mM}$ ): 215 sucrose, $2.5 \mathrm{KCl}, 1.25 \mathrm{NaH}_{2} \mathrm{PO}_{4}, 2.8 \mathrm{NaHCO}_{3}, 7$ dextrose, 3 Na-pyruvate, $1 \mathrm{Na}$-ascorbate, $0.5 \mathrm{CaCl}_{2}$, and $7 \mathrm{MgCl}_{2}\left(\mathrm{pH} 7.4\right.$, oxygenated with $95 \% \mathrm{CO}_{2}$ and $5 \% \mathrm{O}_{2}$ ). After sectioning, slices were transferred to a warmed $\left(35^{\circ} \mathrm{C}\right)$ incubation chamber for 30 minutes with bubbled aCSF consisting of (in $\mathrm{mM}$ ): $125 \mathrm{NaCl}$, $2.5 \mathrm{KCl}, 1.25 \mathrm{NaH}_{2} \mathrm{PO}_{4}, 25 \mathrm{NaHCO}_{3}, 25$ dextrose, $2 \mathrm{CaCl}_{2}, 1 \mathrm{MgCl}_{2}, 3 \mathrm{Na}$-pyruvate, and $1 \mathrm{Na}$-ascorbate. Slices were then maintained in bubbled aCSF at RT until transferred to the recording chamber.

Whole-cell current-clamp recordings were conducted as previously described (54, 55). Briefly, during recordings, slices were continuously perfused with bubbled aCSF and maintained at a temperature of $34^{\circ} \mathrm{C}$. Somatic whole-cell current-clamp recordings were made using patch-clamp electrodes pulled from borosilicate glass and filled with intracellular solution containing (in $\mathrm{mM}$ ): $115 \mathrm{~K}$-gluconate, $20 \mathrm{KCl}, 10 \mathrm{Na}$-phosphocreatine, $10 \mathrm{HEPES}, 4 \mathrm{Mg}$-ATP, and $0.3 \mathrm{Na}$-GTP. Electrode resistance in the bath was 4-9 M $\Omega$, and series resistance was 15-25 M 2 ; bridge balance and capacitance compensation were used to minimize the resultant errors. Recordings were made using a Dagan BVC-700 amplifier (Dagan Corporation). Data were low-pass filtered at 3 or $5 \mathrm{kHz}$ and were digitized at $50 \mathrm{kHz}$ via an ITC18 digital-analog converter (HEKA Instruments Inc.) under control of IGOR Pro (Wavemetrics) using the DataPro software package from the lab of Nelson Spruston (www.janelia.org/lab/ spruston-lab/resources/software). Patched cells were maintained at a potential of $-65 \mathrm{mV}$, with a holding current when needed no larger than $\pm 100 \mathrm{pA}$. A $100-\mathrm{Hz}$ burst of 5 somatic spikes was induced by current injection (+2000 pA, $2 \mathrm{~ns}, \times 5)$, with an ISI of 20 seconds. Baseline responses were recorded for 3 minutes before beginning drug or vehicle perfusion. Recordings lasted for 30 minutes after the baseline recording period. Drug perfusion lasted for 15 minutes before washout.

Electrophysiological data was analyzed using custom scripts written for use with IGOR Pro software and the DataPro package. Statistical analyses were performed using STATISTICA 11 software and Prism 6 software (GraphPad). Data from multiple cells was pooled and tested for statistically significant differences using unpaired 2-tailed Student's $t$ tests, a 1-way repeated-measures ANOVA with Tukey's post hoc comparisons, or 2-way ANOVA with Holm-Sidak's multiple comparisons test. For all tests, significance was defined as $P<0.05$.

Drugs. All drugs used in the electrophysiology experiments were mixed as stock solutions and stored as individual aliquots at $-20^{\circ} \mathrm{C}$, except for DHPG, which was made fresh for each experiment. The HDAC inhibitor TSA (AG Scientific) was mixed as a $16.5 \mathrm{mM}$ stock solution in $50 \%$ ethanol (6) and diluted to a final concentration of $1.65 \mu \mathrm{M}$ in aCSF. The Group I mGluR agonist DHPG (Tocris) was mixed fresh for each experiment as a $50-\mathrm{mM}$ solution in $\mathrm{ddH}_{2} \mathrm{O}$ and used at a final concentration of $12 \mu \mathrm{M}$ in aCSF. MPEP (AbCam) was mixed as a $5-\mathrm{mM}$ stock solution in $\mathrm{ddH}_{2} \mathrm{O}$ and diluted to a final concentration of $40 \mu \mathrm{M}$ in aCSF. LY367385 (AbCam) was mixed as a 50-mM stock solution in equimolar $\mathrm{NaOH}$ and diluted to a final concentration of $100 \mu \mathrm{M}$ in aCSF. The RNA synthesis inhibitor actinomycin D was dissolved in DMSO at a stock concentration of $50 \mathrm{mM}$ and was diluted to a final concentration of $25 \mu \mathrm{M}$ in aCSF (6). For LTP experiments, drug application was initiated 20 minutes prior to induction and lasted for 10 minutes (mGluR antagonists) or for the duration of the recording (TSA and Actinomycin-D). 
Statistical analyses. Initial slope of the fEPSP was used to quantify synaptic potentiation, normalized to the averaged value of the 20-minute baseline. Only 1 slice per animal was included in any treatment condition. Within each LTP experiment, recordings were made from multiple slices from each mouse whenever possible to reduce the number of animals used. The order of treatment was determined randomly on each day of recording. Sample sizes were not predetermined using statistical methods, but the sample sizes in our experiments are similar to those reported in similar previously published research from our lab and others $(6,17)$. To evaluate potential differences in paired-pulse facilitation, a repeated measures ANOVA was used with genotype and interstimulus interval as factors and the facilitation ratio as the dependent variable. For evaluation of input-output characteristics, a 2-tailed independent samples $t$ test was performed, comparing the average linear regression slopes for control mice and Sin $3 \mathrm{aNH}$ mice. Potential differences in the maximum fEPSP slope were evaluated using a 2-tailed independent samples $t$ test. Between-group differences in LTP maintenance were determined using a repeated measures ANOVA on the final 20 minutes of the recordings, followed by Tukey's post hoc test when appropriate (6). Normality and variance of LTP data were checked to determine suitability for analysis by ANOVA. Normality of the data was evaluated by Shapiro-Wilk tests and examination of normal probability plots of the residuals. Variance was evaluated by examination of residual plots of observed versus fitted values. All statistical analyses were performed using STATISTICA software (StatSoft Inc.).

\section{Statistics}

Experiment-specific statistical methodology is included in greater detail in the appropriate Methods section. Briefly, all data were tested for normality using Shapiro-Wilk tests before performing statistical comparisons. Between-group comparisons were made using unpaired 2-tailed $t$ tests if normally distributed, or nonparametric Mann-Whitney $U$ tests if nonnormally distributed. When comparisons were made between multiple groups, 2-way ANOVA was used for normally distributed data, followed by Holm-Sidak multiple comparisons test, while an independent samples Kruskal-Wallis test was used for nonparametric data. For comparisons between 2 groups over time, a repeated-measures ANOVA was used, followed by Tukey's post hoc test. Significance for all statistical tests was set at $P<0.05$. In all Figures, significance is indicated as: ${ }^{*} P<0.05 ;{ }^{*} P$ $<0.01 ;{ }^{* *} P<0.001$. All data are presented as individual data points with mean \pm SEM.

\section{Study approval}

All experimental procedures were approved by the IACUC of the University of Pennsylvania (protocol no. 804716) and the IACUC of the HHMI Janelia Research Campus (protocol no. 11-48).

\section{Author contributions}

MB designed research studies, conducted experiments, analyzed data, wrote the manuscript, and edited the manuscript. HS designed research studies, conducted experiments, analyzed data, wrote the manuscript, and edited the manuscript. CF designed research studies, conducted experiments, and analyzed data edited the manuscript. SGP designed research studies, conducted experiments, analyzed data, and edited the manuscript. GSP and CL conducted experiments and analyzed data. AB conducted experiments, analyzed data, and edited the manuscript. JDH designed research studies, analyzed data, and edited the manuscript. CGH designed research studies and edited the manuscript. $\mathrm{RH}$ designed research studies, conducted experiments, analyzed data, and edited the manuscript. KPG designed research studies and edited the manuscript. NS designed research studies and edited the manuscript. TA designed research studies and edited the manuscript.

\section{Acknowledgments}

MB was supported by a predoctoral NRSA fellowship from the NINDS (1F31NS079019). HS was supported by NIH training grant T32-MH017168. The work was supported by NIH grant R01-MH087463 to TA, as well as the Brush Family Professorship (Penn) and the Roy J. Carver Chair in Neuroscience (Iowa). Additional thanks to the entire Spruston lab and the HHMI Janelia Research Campus for providing animal care, training, material, and other resources to MB. Funding to NS was provided by the HHMI.

Address correspondence to: Ted Abel, Iowa Neuroscience Institute, Departments of Molecular Physiology and Biophysics, Psychiatry, and Biochemistry, Carver College of Medicine, University of Iowa, 2312 Pappajohn Biomedical Discovery Building, 169 Newton Road, Iowa City, Iowa 52242-1903, USA. Phone:

Office: 319.383.4534; Email: ted-abel@uiowa.edu. 
MB's present address is: Hussman Institute for Autism, Baltimore, Maryland, USA.

HS's present address is: Department of Biomedical Sciences, Washington State University Spokane, Spokane, Washington, USA.

CF's present address is: Centre de Recherches sur la Cognition Animale, Centre de Biologie Intégrative, Université Paul Sabatier, Toulouse, France.

SGP's present address is: DNA Electronics, San Diego, California, USA.

JDH's present address is: Department of Cellular Neuroscience, Neurodegeneration, and Repair, Yale University, New Haven, Connecticut, USA.

RH's present address is: Groningen Institute for Evolutionary Life Sciences, Faculty of Science and Engineering, University of Groningen, Groningen, Netherlands.

TA's present address is: Carver College of Medicine, University of Iowa, Iowa City, Iowa, USA.

1. Peixoto L, Abel T. The role of histone acetylation in memory formation and cognitive impairments. Neuropsychopharmacology. 2013;38(1):62-76.

2. Fischer A, Sananbenesi F, Mungenast A, Tsai LH. Targeting the correct HDAC(s) to treat cognitive disorders. Trends Pharmacol Sci. 2010;31(12):605-617.

3. Levenson JM, O'Riordan KJ, Brown KD, Trinh MA, Molfese DL, Sweatt JD. Regulation of histone acetylation during memory formation in the hippocampus. J Biol Chem. 2004;279(39):40545-40559.

4. Mahan AL, Mou L, Shah N, Hu JH, Worley PF, Ressler KJ. Epigenetic modulation of Homerla transcription regulation in amygdala and hippocampus with pavlovian fear conditioning. J Neurosci. 2012;32(13):4651-4659.

5. Maze I, Noh KM, Allis CD. Histone regulation in the CNS: basic principles of epigenetic plasticity. Neuropsychopharmacology. 2013;38(1):3-22.

6. Vecsey CG, et al. Histone deacetylase inhibitors enhance memory and synaptic plasticity via CREB:CBP-dependent transcriptional activation. J Neurosci. 2007;27(23):6128-6140.

7. McQuown SC, et al. HDAC3 is a critical negative regulator of long-term memory formation. J Neurosci. 2011;31(2):764-774.

8. Guan JS, et al. HDAC2 negatively regulates memory formation and synaptic plasticity. Nature. 2009;459(7243):55-60.

9. Vo N, Goodman RH. CREB-binding protein and p300 in transcriptional regulation. J Biol Chem. 2001;276(17):13505-13508

10. Alarcón JM, et al. Chromatin acetylation, memory, and LTP are impaired in CBP+/- mice: a model for the cognitive deficit in Rubinstein-Taybi syndrome and its amelioration. Neuron. 2004;42(6):947-959.

11. Oliveira AM, Wood MA, McDonough CB, Abel T. Transgenic mice expressing an inhibitory truncated form of p300 exhibit long-term memory deficits. Learn Mem. 2007;14(9):564-572.

12. Schoch H, Abel T. Transcriptional co-repressors and memory storage. Neuropharmacology. 2014;80:53-60.

13. Grzenda A, Lomberk G, Zhang JS, Urrutia R. Sin3: master scaffold and transcriptional corepressor. Biochim Biophys Acta. $2009 ; 1789(6-8): 443-450$.

14. Silverstein RA, Ekwall K. Sin3: a flexible regulator of global gene expression and genome stability. Curr Genet. 2005;47(1):1-17.

15. Bahari-Javan S, et al. HDAC1 regulates fear extinction in mice. J Neurosci. 2012;32(15):5062-5073.

16. Witteveen JS, et al. Haploinsufficiency of MeCP2-interacting transcriptional co-repressor SIN3A causes mild intellectual disability by affecting the development of cortical integrity. Nat Genet. 2016;48(8):877-887.

17. Havekes R, et al. Gravin orchestrates protein kinase A and $\beta 2$-adrenergic receptor signaling critical for synaptic plasticity and memory. J Neurosci. 2012;32(50):18137-18149.

18. Maren S, Fanselow MS. Electrolytic lesions of the fimbria/fornix, dorsal hippocampus, or entorhinal cortex produce anterograde deficits in contextual fear conditioning in rats. Neurobiol Learn Mem. 1997;67(2):142-149.

19. Trifilieff $\mathrm{P}$, et al. Foreground contextual fear memory consolidation requires two independent phases of hippocampal ERK/ CREB activation. Learn Mem. 2006;13(3):349-358.

20. Bourtchouladze R, Abel T, Berman N, Gordon R, Lapidus K, Kandel ER. Different training procedures recruit either one or two critical periods for contextual memory consolidation, each of which requires protein synthesis and PKA. Learn Mem 1998;5(4-5):365-374.

21. Igaz LM, Vianna MR, Medina JH, Izquierdo I. Two time periods of hippocampal mRNA synthesis are required for memory consolidation of fear-motivated learning. J Neurosci. 2002;22(15):6781-6789.

22. Phillips RG, LeDoux JE. Differential contribution of amygdala and hippocampus to cued and contextual fear conditioning. Behav Neurosci. 1992;106(2):274-285.

23. Maren S. Synaptic mechanisms of associative memory in the amygdala. Neuron. 2005;47(6):783-786.

24. Sewal AS, et al. Experience Modulates the Effects of Histone Deacetylase Inhibitors on Gene and Protein Expression in the Hippocampus: Impaired Plasticity in Aging. J Neurosci. 2015;35(33):11729-11742.

25. Benito E, et al. HDAC inhibitor-dependent transcriptome and memory reinstatement in cognitive decline models. $J$ Clin Invest. 2015;125(9):3572-3584. 
26. Kundaje A, et al. Ubiquitous heterogeneity and asymmetry of the chromatin environment at regulatory elements. Genome Res. 2012;22(9):1735-1747.

27. Rosenbloom KR, et al. ENCODE data in the UCSC Genome Browser: year 5 update. Nucleic Acids Res. 2013;41(Database issue):D56-D63.

28. Orlando LR, et al. Phosphorylation of the homer-binding domain of group I metabotropic glutamate receptors by cyclin-dependent kinase 5. J Neurochem. 2009;110(2):557-569.

29. Shiraishi-Yamaguchi Y, Furuichi T. The Homer family proteins. Genome Biol. 2007;8(2):206.

30. Mao L, Yang L, Tang Q, Samdani S, Zhang G, Wang JQ. The scaffold protein Homer1b/c links metabotropic glutamate receptor 5 to extracellular signal-regulated protein kinase cascades in neurons. J Neurosci. 2005;25(10):2741-2752.

31. Tu JC, et al. Coupling of mGluR/Homer and PSD-95 complexes by the Shank family of postsynaptic density proteins. Neuron. 1999;23(3):583-592.

32. Xiao B, et al. Homer regulates the association of group 1 metabotropic glutamate receptors with multivalent complexes of homer-related, synaptic proteins. Neuron. 1998;21(4):707-716.

33. Bottai D, et al. Synaptic activity-induced conversion of intronic to exonic sequence in Homer 1 immediate early gene expression. J Neurosci. 2002;22(1):167-175.

34. Kammermeier PJ, Worley PF. Homer 1a uncouples metabotropic glutamate receptor 5 from postsynaptic effectors. Proc Natl Acad Sci USA. 2007;104(14):6055-6060.

35. Neyman S, Manahan-Vaughan D. Metabotropic glutamate receptor 1 (mGluR1) and 5 (mGluR5) regulate late phases of LTP and LTD in the hippocampal CA1 region in vitro. Eur J Neurosci. 2008;27(6):1345-1352.

36. Ménard C, Quirion R. Successful cognitive aging in rats: a role for mGluR5 glutamate receptors, homer 1 proteins and downstream signaling pathways. PLoS One. 2012;7(1):e28666.

37. Manahan-Vaughan D, Braunewell KH. The metabotropic glutamate receptor, mGluR5, is a key determinant of good and bad spatial learning performance and hippocampal synaptic plasticity. Cereb Cortex. 2005;15(11):1703-1713.

38. Jia Z, et al. Selective abolition of the NMDA component of long-term potentiation in mice lacking mGluR5. Learn Mem. 1998;5(4-5):331-343.

39. Rae MG, Irving AJ. Both mGluR1 and mGluR5 mediate Ca2+ release and inward currents in hippocampal CA1 pyramida neurons. Neuropharmacology. 2004;46(8):1057-1069.

40. Anwyl R. Metabotropic glutamate receptor-dependent long-term potentiation. Neuropharmacology. 2009;56(4):735-740.

41. Piers TM, Kim DH, Kim BC, Regan P, Whitcomb DJ, Cho K. Translational Concepts of mGluR5 in Synaptic Diseases of the Brain. Front Pharmacol. 2012;3:199.

42. Kotecha SA, Jackson MF, Al-Mahrouki A, Roder JC, Orser BA, MacDonald JF. Co-stimulation of mGluR5 and N-methyl-D-aspartate receptors is required for potentiation of excitatory synaptic transmission in hippocampal neurons. $J$ Biol Chem. 2003;278(30):27742-27749.

43. Mannaioni G, Marino MJ, Valenti O, Traynelis SF, Conn PJ. Metabotropic glutamate receptors 1 and 5 differentially regulate CA1 pyramidal cell function. J Neurosci. 2001;21(16):5925-5934.

44. Ferraguti F, Crepaldi L, Nicoletti F. Metabotropic glutamate 1 receptor: current concepts and perspectives. Pharmacol Rev. 2008;60(4):536-581.

45. Ménard C, Quirion R. Group 1 metabotropic glutamate receptor function and its regulation of learning and memory in the aging brain. Front Pharmacol. 2012;3:182

46. Uslaner JM, et al. Dose-dependent effect of CDPPB, the mGluR5 positive allosteric modulator, on recognition memory is associated with GluR1 and CREB phosphorylation in the prefrontal cortex and hippocampus. Neuropharmacology 2009;57(5-6):531-538.

47. Balschun D, Zuschratter W, Wetzel W. Allosteric enhancement of metabotropic glutamate receptor 5 function promotes spatial memory. Neuroscience. 2006;142(3):691-702.

48. Ayala JE, et al. mGluR5 positive allosteric modulators facilitate both hippocampal LTP and LTD and enhance spatial learning. Neuropsychopharmacology. 2009;34(9):2057-2071.

49. Klugmann M, et al. AAV-mediated hippocampal expression of short and long Homer 1 proteins differentially affect cognition and seizure activity in adult rats. Mol Cell Neurosci. 2005;28(2):347-360.

50. Thomas GM, Huganir RL. MAPK cascade signalling and synaptic plasticity. Nat Rev Neurosci. 2004;5(3):173-183

51. O'Riordan K, Gerstein H, Hullinger R, Burger C. The role of Homer1c in metabotropic glutamate receptor-dependent long term potentiation. Hippocampus. 2014;24(1):1-6.

52. Clifton NE, Trent S, Thomas KL, Hall J. Regulation and Function of Activity-Dependent Homer in Synaptic Plasticity. Mol Neuropsychiatry. 2019;5(3):147-161.

53. Gerstein H, O'Riordan K, Osting S, Schwarz M, Burger C. Rescue of synaptic plasticity and spatial learning deficits in the hip pocampus of Homer1 knockout mice by recombinant Adeno-associated viral gene delivery of Homer1c. Neurobiol Learn Mem 2012;97(1):17-29.

54. Park JY, et al. A post-burst after depolarization is mediated by group i metabotropic glutamate receptor-dependent upregulation of Ca(v)2.3 R-type calcium channels in CA1 pyramidal neurons. PLoS Biol. 2010;8(11):e1000534.

55. Park JY, Spruston N. Synergistic actions of metabotropic acetylcholine and glutamate receptors on the excitability of hippocampal CA1 pyramidal neurons. J Neurosci. 2012;32(18):6081-6091.

56. Metz AE, Jarsky T, Martina M, Spruston N. R-type calcium channels contribute to afterdepolarization and bursting in hippocampal CA1 pyramidal neurons. J Neurosci. 2005;25(24):5763-5773.

57. Heiman M, et al. A translational profiling approach for the molecular characterization of CNS cell types. Cell. 2008;135(4):738-748

58. Heiman M, Kulicke R, Fenster RJ, Greengard P, Heintz N. Cell type-specific mRNA purification by translating ribosome affinity purification (TRAP). Nat Protoc. 2014;9(6):1282-1291.

59. Sevastyanova TN, Kammermeier PJ. Cooperative signaling between homodimers of metabotropic glutamate receptors 1 and 5. Mol Pharmacol. 2014;86(5):492-504.

60. Yu W, Sohn JW, Kwon J, Lee SH, Kim S, Ho WK. Enhancement of dendritic persistent $\mathrm{Na}^{+}$currents by mGluR5 leads to an 
advancement of spike timing with an increase in temporal precision. Mol Brain. 2018;11(1):67.

61. Mao LM, Wang JQ. Regulation of Group I Metabotropic Glutamate Receptors by MAPK/ERK in Neurons. J Nat Sci. 2016;2(12):e268.

62. Komiyama NH, et al. SynGAP regulates ERK/MAPK signaling, synaptic plasticity, and learning in the complex with postsynaptic density 95 and NMDA receptor. J Neurosci. 2002;22(22):9721-9732.

63. Basu T, et al. Histone deacetylase inhibitors restore normal hippocampal synaptic plasticity and seizure threshold in a mouse model of Tuberous Sclerosis Complex. Sci Rep. 2019;9(1):5266.

64. Gimse K, Gorzek RC, Olin A, Osting S, Burger C. Hippocampal Homer1b/c is necessary for contextual fear conditioning and group I metabotropic glutamate receptor mediated long-term depression. Neurobiol Learn Mem. 2018;156:17-23.

65. Abel T, Zukin RS. Epigenetic targets of HDAC inhibition in neurodegenerative and psychiatric disorders. Curr Opin Pharmacol. 2008;8(1):57-64.

66. Szumlinski KK, Kalivas PW, Worley PF. Homer proteins: implications for neuropsychiatric disorders. Curr Opin Neurobiol. 2006;16(3):251-257.

67. Nicoletti F, et al. Metabotropic glutamate receptors: from the workbench to the bedside. Neuropharmacology. 2011;60(7-8):1017-1041

68. Rojas DC. The role of glutamate and its receptors in autism and the use of glutamate receptor antagonists in treatment. $J$ Neural Transm (Vienna). 2014;121(8):891-905.

69. Wenger TL, et al. The Role of mGluR Copy Number Variation in Genetic and Environmental Forms of Syndromic Autism Spectrum Disorder. Sci Rep. 2016;6:19372.

70. Kelleher RJ, et al. High-throughput sequencing of mGluR signaling pathway genes reveals enrichment of rare variants in autism. PLoS One. 2012;7(4):e35003.

71. Fatemi SH, Folsom TD, Kneeland RE, Liesch SB. Metabotropic glutamate receptor 5 upregulation in children with autism is associated with underexpression of both Fragile X mental retardation protein and GABAA receptor beta 3 in adults with autism. Anat Rec (Hoboken). 2011;294(10):1635-1645.

72. Dölen G, Bear MF. Role for metabotropic glutamate receptor 5 (mGluR5) in the pathogenesis of fragile X syndrome. J Physiol (Lond). 2008;586(6):1503-1508.

73. Lee AW, Ventola P, Budimirovic D, Berry-Kravis E, Visootsak J. Clinical Development of Targeted Fragile X Syndrome Treatments: An Industry Perspective. Brain Sci. 2018;8(12):E214.

74. Hagerman R, et al. Mavoglurant in Fragile X Syndrome: Results of two open-label, extension trials in adults and adolescents. Sci Rep. 2018;8(1):16970.

75. Berry-Kravis E, et al. Mavoglurant in fragile X syndrome: Results of two randomized, double-blind, placebo-controlled trials. Sci Transl Med. 2016;8(321):321ra5.

76. Dannenberg JH, David G, Zhong S, van der Torre J, Wong WH, Depinho RA. mSin3A corepressor regulates diverse transcriptional networks governing normal and neoplastic growth and survival. Genes Dev. 2005;19(13):1581-1595.

77. Dragatsis I, Zeitlin S. CaMKIIalpha-Cre transgene expression and recombination patterns in the mouse brain. Genesis. 2000;26(2):133-135.

78. Hawk JD, et al. NR4A nuclear receptors support memory enhancement by histone deacetylase inhibitors. J Clin Invest. 2012;122(10):3593-3602.

79. Banerjee A, et al. Src kinase as a mediator of convergent molecular abnormalities leading to NMDAR hypoactivity in schizophrenia. Mol Psychiatry. 2015;20(9):1091-1100.

80. Hahn CG, et al. The post-synaptic density of human postmortem brain tissues: an experimental study paradigm for neuropsychiatric illnesses. PLoS One. 2009;4(4):e5251. 